\title{
Fatty acids as dietary tracers in benthic food webs
}

\author{
Jennifer R. Kelly*, Robert E. Scheibling \\ Biology Department, Dalhousie University, Halifax, Nova Scotia B3H 4J1, Canada
}

ABSTRACT: Fatty acid (FA) analysis is a wellestablished tool for studying trophic interactions in marine habitats. However, its application to benthic food webs poses 2 particular challenges. First, unlike pelagic zooplankton, benthic consumers have access to different sizes and functional groups of primary producers and may consume a highly mixed diet. Classes of benthic primary producers are distinct in their overall FA composition, but most do not possess unique marker FAs that can be used to identify their contribution to higher trophic levels. Second, unlike mammalian predators, benthic invertebrates have the capacity to significantly modify their dietary FAs and thereby obscure markers for food sources. Controlled feeding studies have been used to distinguish dietary tracer FAs from those that are modified by the consumer in several benthic invertebrates, but more such studies are needed. Despite these challenges, FAs have been used to study trophic structure in a variety of benthic habitats including the deep sea, polar regions, estuaries, and the rocky subtidal zone. However, the complexity of benthic food webs and lack of unique markers impose uncertainties in the interpretation of FA data from field studies. Multivariate analyses are necessary for analyzing FA datasets, although univariate tests can be useful for comparing levels of informative FAs among food sources and consumers. Combining FA analysis with other lines of evidence, such as stable isotope analysis, offers a more reliable approach to examining trophic interactions in benthic systems.

KEY WORDS: Fatty acids - Trophic interactions Benthic consumers · Macroalgae · Invertebrates

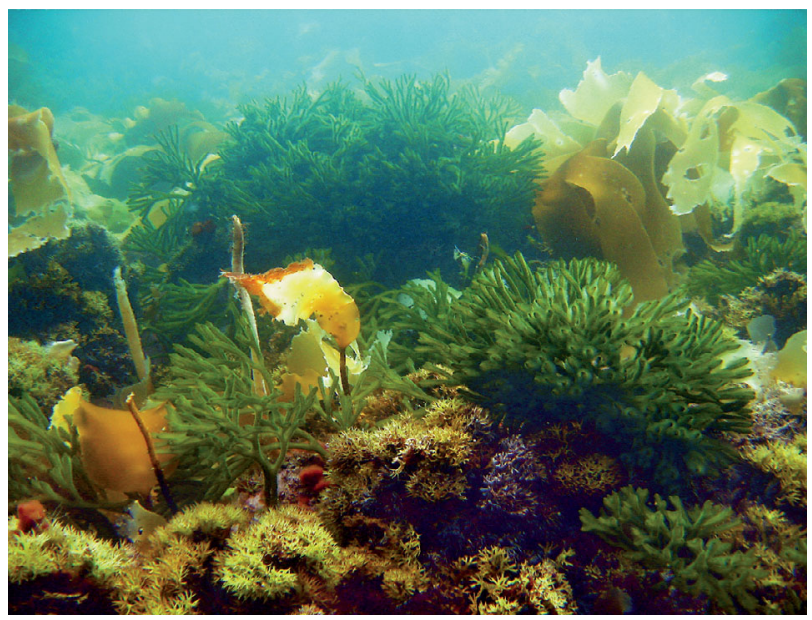

The diversity of benthic primary producers poses a challenge for identifying the diets of invertebrate grazers using fatty acid analysis.

Photo: Robert Scheibling

\section{INTRODUCTION}

Identifying the diets of animals is important for understanding their basic ecology, characterizing trophic interactions, and predicting community-level consequences of biotic and abiotic change. In the marine environment, direct observation of feeding is often impractical or impossible, so ecologists have developed indirect methods for examining diet. Physical methods such as analyzing gut contents or fecal pellets have been used extensively, but these can underestimate the importance of soft and highly digestible food items and overestimate that of recently consumed items (Graeve et al. 2001, Latyshev 
et al. 2004). These methods may also be inappropriate for invertebrates with unusual modes of feeding or digestion; for example, many sea stars feed extra-orally and are rarely observed with any gut contents (Howell et al. 2003). Biochemical tracer methods such as stable isotope or fatty acid (FA) analysis have the advantage of potentially providing less biased, longer-term dietary information (Iverson et al. 2004).

FAs have been used extensively in pelagic food webs, especially to identify phytoplankton and characterize the diets of zooplankton (reviewed by Dalsgaard et al. 2003). Diatoms and dinoflagellates are distinct in their FA composition, and zooplankton tend to retain dietary FAs in their tissues. Calanoid copepods also synthesize a few relatively rare FAs that can be used to identify their contribution to the diets of higher-order consumers (Sargent \& FalkPetersen 1988, Dalsgaard et al. 2003). Top predators have also been successfully studied using FA analyses; dietary FAs are deposited in the blubber of marine mammals with relatively little modification, facilitating accurate characterization of their diets (reviewed by Budge et al. 2006, Iverson 2009).

Unlike pelagic systems, where phytoplankton is the major source of primary production, benthic food webs are supported by a diversity of primary producers that can include macroalgae and vascular plants, in addition to phytoplankton and bacteria (Kharlamenko et al. 2001, Dalsgaard et al. 2003). Although these primary producers have characteristic FA compositions, the larger number of potential food items can pose problems for distinguishing their contributions to diets, particularly when animals consume mixed diets (Kharlamenko et al. 2001, Alfaro et al. 2006). Some invertebrate taxa are capable of modifying dietary FAs such that their FA composition may not directly reflect diet (Kelly et al. 2008, 2009). Most taxa lack a specific fat-storage organ, so other functions of lipid-rich tissues may influence their FA composition to a greater extent than does diet (Hughes et al. 2006). Despite these challenges, many studies have employed FAs to better understand animal diets and trophic relationships in benthic habitats.

In this review, we examine the utility of FAs as bottom-up dietary tracers in benthic marine systems by comparing FA composition among benthic primary producers, summarizing laboratory-based controlled feeding studies, discussing field studies using FAs in various benthic habitats, evaluating statistical analyses for FA data, and comparing stable isotope and FA analyses as techniques for studying benthic food webs. We do not cover extraction or chemical analysis of FAs and refer readers to Budge et al. (2006) for advice on these processes.

\section{FA NOMENCLATURE AND TERMINOLOGY}

FAs consist of a terminal methyl group $\left(\mathrm{CH}_{3}\right)$, a carbon chain, and a terminal carboxyl group ( $\mathrm{COOH})$. Most naturally-occurring FAs have an even number of carbons, usually between 14 and 24, although vascular plants commonly have long-chain FAs of up to 28 carbons in their cuticular waxes (Gurr et al. 2002). Saturated FAs (SFAs) are those with no double bonds, and monounsaturated FAs (MUFAs) have 1 double bond. Polyunsaturated FAs (PUFAs) typically have 2 to 6 double bonds, and these are usually separated by a methylene group $\left(\mathrm{CH}_{2}\right.$ Budge et al. 2006). FAs are named using the notation $\mathrm{A}: \mathrm{Bn}-\mathrm{x}$, where $\mathrm{A}$ is the number of carbons, $B$ is the number of double bonds, and $\mathrm{x}$ is the position of the first double bond relative to the terminal methyl group. A list of abbreviations is given in Table 1.

FAs that are thought to convey dietary information are referred to in the literature as markers, indicators, and tracers, and these terms are used somewhat interchangeably. For the purpose of this review, we define a marker FA as one with an origin that can be unambiguously identified within the habitat of interest. Since markers unique to a given taxonomic group are relatively rare, we also discuss indicator FAs as those that are elevated in certain taxa, but may be found at lower concentrations in others. Both the presence and relative abundance of indicator FAs should therefore be taken into consideration when using these FAs to infer diet. We use 'tracer' as a general term that includes the use of marker or indicator FAs to track the flow of material through food webs.

Table 1. Abbreviations used throughout this review

\begin{tabular}{ll}
\hline FA & Fatty acid \\
\hline SFA & Saturated FA: FA with no double bonds \\
MUFA & Monounsaturated FA: FA with 1 double bond \\
PUFA & Polyunsaturated FA: FA with $\geq 2$ double bonds \\
HUFA & Highly unsaturated FA: PUFA with $\geq 4$ double bonds \\
LCFA & Long-chain FA: FA with $\geq 24$ carbons \\
C $_{x}$ & Refers to the number of carbons in FA, e.g. $C_{18}=18$ carbons \\
SI & Stable isotope
\end{tabular}




\section{PRIMARY PRODUCER AND BACTERIAL FA}

Phytoplankton are the base of pelagic food webs, and the main taxa of pelagic phytoplankton have distinct FA compositions (Dalsgaard et al. 2003). These microalgae also contribute to benthic food webs, and in some cases the presence of their characteristic FAs in benthic organisms indicates a trophic connection between pelagic and benthic food webs (Kharlamenko et al. 1995, Graeve et al. 1997, Parrish et al. 2009). Benthic food webs also rely on macroalgae, vascular plants (such as mangroves and seagrass), and bacteria, and these food sources also have characteristic FA compositions that can be used to identify their contributions to higher trophic levels (Dalsgaard et al. 2003).

To identify potential indicator FAs and compare overall FA composition of marine primary producers, we used similarity-based multivariate techniques (see 'Statistical analysis of FA data') to analyze FA data from 6 taxonomic groups of primary producers from 27 published studies (Table 2). While the focus of this review is on benthic systems, we have included phytoplankton FA data in this analysis because they enter benthic food webs as phytodetritus or by being consumed by suspension feeders. There were significant differences in overall FA composition among vascular plants, diatoms, dinoflagellates, and green, brown, and red macroalgae (analysis of similarity, ANOSIM, $\mathrm{R}=0.793, \mathrm{p}<0.001$ ). These taxa generally were separated in multivariate space using a 2-dimensional multidimensional scaling (MDS) plot (Fig. 1), although the stress value (0.21) is relatively high (stress $=0.13$ for 3-dimensional MDS). All pairwise comparisons were significant $(p<0.001)$, although green algae and vascular plants were not well separated (ANOSIM, R $=0.47$ ) compared to other groups $(\mathrm{R}>0.7$, see 'Statistical analysis of FA data'). We used similarity percentage analysis (SIMPER) to identify FAs that contributed at least $10 \%$ to within-group similarity for only 1 group: 18:1n-7 and 16:4n-3 for green algae; $18: 4 n-3$ for brown algae; 22:6n-3 for dinoflagellates; and 16:1n-7 and 16:3n-4 for diatoms (Table 3). However, we also found several commonly-used indicators that were identified as contributing at least $10 \%$ to within-group similarity for multiple groups: 20:5n-3 was identified for dinoflagellates, diatoms, and brown and red macroalgae; $20: 4 n-6$ for both brown and red algae; $18: 1 n-9$ for brown and red algae, vascular plants, and dinoflagellates; and 18:2n-6 and 18:3n-3 for green algae and vascular plants (Table 3). This overlap indicates the need for caution when interpreting single FAs as tracers for primary producers (Sargent et al. 1987, Dalsgaard et al. 2003).

\section{Algae}

De novo synthesis of algal FAs occurs in the chloroplasts and results in the production of SFAs, typically 16:0, from acetyl-CoA (Gurr et al. 2002). These SFAs are modified through a series of elongation and desaturation steps to produce various unsaturated FAs (Fig. 2). Conversion from 18:1n-9 to 18:2n-6 and 18:3n-3 requires $\Delta 12$ and $\Delta 15$ desaturase enzymes found only in primary producers. These 2 PUFAs are therefore called 'essential' FAs because animals must obtain them from their diets rather than by modifying other FAs (Dalsgaard et al. 2003). Further elongation and desaturation of $18: 2 \mathrm{n}-6$ and $18: 3 \mathrm{n}-3$ produce other common marine PUFAs including 20:4n-6, 20:5n-3, and 22:6n-3 (Gurr et al. 2002; Fig. 2). An alternative pathway, in which 16:0 is desaturated to $16: 1 \mathrm{n}-7$ and then further desaturated to $16: 4 \mathrm{n}-1$, is characteristic of diatoms, and both of these FAs are commonly used as indicators for diatoms (Dalsgaard et al. 2003).

The contributions of major microalgal taxa to benthic food webs are often estimated based on FA composition (Graeve et al. 2001, Howell et al. 2003, Guest et al. 2008). Diatoms and dinoflagellates have characteristic FA compositions that have been used as indicators in environmental samples (e.g. sediment or suspended matter) and in consumer tissues (Dalsgaard et al. 2003). Diatoms are frequently found in benthic environments as epiphytes (Nichols et al. 1986, Latyshev et al. 2004, Richoux \& Froneman 2008), and both diatoms and dinoflagellates are captured from the water column by suspension feeders and from sediments by deposit feeders (Graeve et al. 2001, Howell et al. 2003, Guest et al. 2008). Diatoms are characterized by relatively high concentrations of 16:1n-7, 16:4n-1, and 20:5n-3, while dinoflagellates are typically rich in 22:6n-3 and 18:4n-3 (Budge \& Parrish 1998, Dalsgaard et al. 2003). FA ratios are often used to distinguish between diatom and dinoflagellate dominance in phytoplankton samples: 16:1n-7/16:0 >1 or 20:5n-3/22:6n-3 >1 indicate diatom dominance (Budge \& Parrish 1998, Dalsgaard et al. 2003; our Appendix 1). In our analysis of primary producer FA composition, diatoms and dinoflagellates are distinguished from each other by 16:1n-7 and $20: 5 n-3$, which are more abundant in diatoms, and by 22:6n-3 and 18:1n-9, which are more abundant in dinoflagellates (Table 3). 
Table 2. Studies used for analysis of primary producer fatty acid composition data (total 210 records, 111 species)

\begin{tabular}{|c|c|c|c|}
\hline Taxon & No. of species & Location & Source \\
\hline $\begin{array}{l}\text { Phylum Ochrophyta, } \\
\text { Class Bacillariophyceae } \\
\text { (diatoms) }\end{array}$ & $\begin{array}{l}14 \\
6 \\
2 \\
2 \\
1 \\
6 \\
4\end{array}$ & $\begin{array}{l}\text { Cultured } \\
\text { Darwin Harbour, Australia } \\
\text { Gulf of Carpentaria, Australia } \\
\text { Queensland, Aus } \\
\text { SE South Africa } \\
\text { Cultured } \\
\text { Cultured }\end{array}$ & $\begin{array}{l}\text { Dunstan et al. (1994) } \\
\text { Renaud et al. (1994) } \\
\text { Renaud et al. (1999) } \\
\text { Renaud et al. (1999) } \\
\text { Richoux \& Froneman (2008) } \\
\text { Viso \& Marty (1993) } \\
\text { Volkman et al. (1989) }\end{array}$ \\
\hline $\begin{array}{l}\text { Phylum Dinoflagellata } \\
\text { (dinoflagellates) }\end{array}$ & $\begin{array}{l}5 \\
1 \\
3 \\
6 \\
3\end{array}$ & $\begin{array}{l}\text { Cultured } \\
\text { Penang, Straits of Malacca } \\
\text { Sebatu, Straits of Malacca } \\
\text { South China Sea } \\
\text { Cultured }\end{array}$ & $\begin{array}{l}\text { Mansour et al. (1999) } \\
\text { Usup et al. (2008) } \\
\text { Usup et al. (2008) } \\
\text { Usup et al. (2008) } \\
\text { Viso \& Marty (1993) }\end{array}$ \\
\hline $\begin{array}{l}\text { Phylum Chlorophyta } \\
\text { (green algae) }\end{array}$ & $\begin{array}{l}2 \\
1 \\
1 \\
1 \\
2 \\
1 \\
1 \\
1 \\
3 \\
3 \\
1 \\
1 \\
1 \\
1 \\
1 \\
8\end{array}$ & $\begin{array}{l}\text { Brittany Coast, France } \\
\text { Antarctic } \\
\text { Spitsbergen, Arctic } \\
\text { Nova Scotia, Canada } \\
\text { Indian Ocean } \\
\text { Sea of Japan } \\
\text { South China Sea } \\
\text { Yellow Sea } \\
\text { Northern California, USA } \\
\text { Bohai Sea } \\
\text { Okinawa, Japan } \\
\text { Southern California, USA } \\
\text { Northern Chile } \\
\text { SE South Africa } \\
\text { Sea of Japan } \\
\text { Yellow Sea }\end{array}$ & $\begin{array}{l}\text { Fleurence et al. (1994) } \\
\text { Graeve et al. (2002) } \\
\text { Graeve et al. (2002) } \\
\text { Kelly et al. (2009) } \\
\text { Khotimchenko (2003) } \\
\text { Khotimchenko (2003) } \\
\text { Khotimchenko (2003) } \\
\text { Khotimchenko (2003) } \\
\text { Khotimchenko et al. (2002) } \\
\text { Li et al. (2002) } \\
\text { Meziane \& Tsuchiya (2002) } \\
\text { Nelson et al. (2002) } \\
\text { Ortiz et al. (2009) } \\
\text { Richoux \& Froneman (2008) } \\
\text { Sanina et al. (2004) } \\
\text { Vaskovsky et al. (1996) }\end{array}$ \\
\hline $\begin{array}{l}\text { Phylum Ochrophyta, } \\
\text { Class Phaeophyceae } \\
\text { (brown algae) }\end{array}$ & $\begin{array}{c}1 \\
5 \\
3 \\
3 \\
1 \\
3 \\
4 \\
15 \\
2 \\
9 \\
10 \\
1 \\
1 \\
2 \\
6\end{array}$ & $\begin{array}{l}\text { Northern New Zealand } \\
\text { Brittany Coast, France } \\
\text { Antarctica } \\
\text { Spitsbergen, Arctic } \\
\text { Cultured } \\
\text { Nova Scotia, Canada } \\
\text { Kurile Islands } \\
\text { Sea of Japan } \\
\text { Sea of Japan } \\
\text { Northern California, USA } \\
\text { Bohai Sea } \\
\text { Southern California, USA } \\
\text { Cultured } \\
\text { Sea of Japan } \\
\text { Yellow Sea }\end{array}$ & $\begin{array}{l}\text { Alfaro et al. (2006) } \\
\text { Fleurence et al. (1994) } \\
\text { Graeve et al. (2002) } \\
\text { Graeve et al. (2002) } \\
\text { Honya et al. (1994) } \\
\text { Kelly et al. (2008) } \\
\text { Khotimchenko (1998) } \\
\text { Khotimchenko (1998) } \\
\text { Khotimchenko \& Kulikova (1999) } \\
\text { Khotimchenko et al. (2002) } \\
\text { Li et al. (2002) } \\
\text { Nelson et al. (2002) } \\
\text { Ortiz et al. (2009) } \\
\text { Sanina et al. (2004) } \\
\text { Vaskovsky et al. (1996) }\end{array}$ \\
\hline $\begin{array}{l}\text { Phylum Rhodophyta } \\
\text { (red algae) }\end{array}$ & $\begin{array}{c}4 \\
11 \\
4 \\
1 \\
1 \\
7 \\
9 \\
1 \\
1 \\
12\end{array}$ & $\begin{array}{l}\text { Brittany Coast, France } \\
\text { Antarctica } \\
\text { Spitsbergen, Arctic } \\
\text { Nova Scotia, Canada } \\
\text { Sea of Japan } \\
\text { Northern California, USA } \\
\text { Bohai Sea } \\
\text { Southern California, USA } \\
\text { Cultured } \\
\text { Yellow Sea }\end{array}$ & $\begin{array}{l}\text { Fleurence et al. (1994) } \\
\text { Graeve et al. (2002) } \\
\text { Graeve et al. (2002) } \\
\text { Kelly et al. (2008) } \\
\text { Khotimchenko (2005) } \\
\text { Khotimchenko et al. (2002) } \\
\text { Li et al. (2002) } \\
\text { Nelson et al. (2002) } \\
\text { Ortiz et al. (2009) } \\
\text { Vaskovsky et al. (1996) }\end{array}$ \\
\hline $\begin{array}{l}\text { Phylum Tracheophyta } \\
\text { (vascular plants) }\end{array}$ & $\begin{array}{l}2 \\
1 \\
1 \\
1 \\
4 \\
2\end{array}$ & $\begin{array}{l}\text { Northern New Zealand } \\
\text { NE Australia } \\
\text { Sea of Japan } \\
\text { Okinawa, Japan } \\
\text { SE South Africa } \\
\text { Yellow Sea }\end{array}$ & $\begin{array}{l}\text { Alfaro et al. (2006) } \\
\text { Hall et al. (2006) } \\
\text { Kharlamenko et al. (2001) } \\
\text { Meziane \& Tsuchiya (2002) } \\
\text { Richoux \& Froneman (2008) } \\
\text { Vaskovsky et al. (1996) }\end{array}$ \\
\hline
\end{tabular}




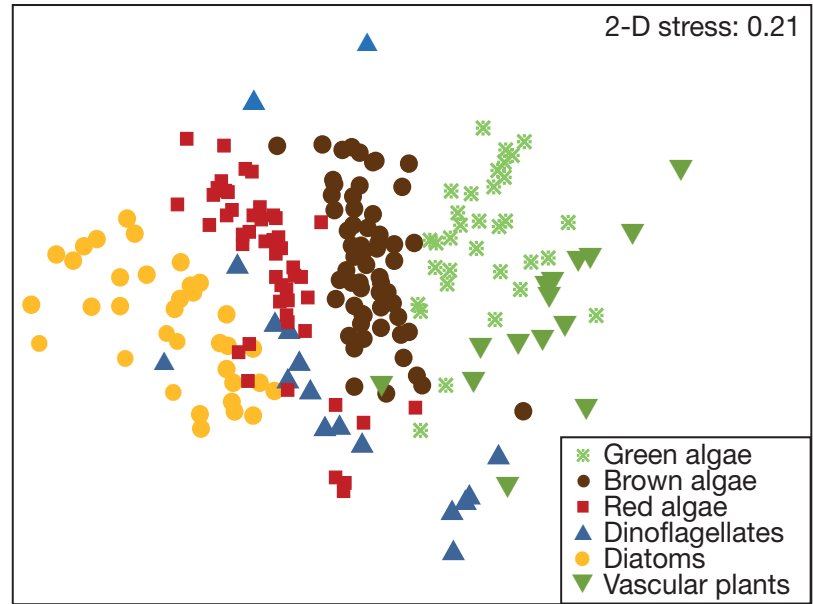

Fig. 1. Non-metric multidimensional scaling (MDS) plot based on Bray-Curtis similarities of fatty acid (FA) data for 6 taxa of primary producers (see Table 2). FAs with average contribution $\geq 0.1 \%$ were included; data were standardized to equal $100 \%$ prior to analysis. Each point represents a species from a particular field site or laboratory culture

Table 3. Results of similarity percentage analysis (SIMPER) of fatty acid (FA) data for primary producers (see Table 2). FAs with average contribution $\geq 0.1 \%$ included; data were not transformed prior to analysis

\begin{tabular}{|c|c|c|c|}
\hline Taxon & FA & $\begin{array}{l}\text { Average } \\
\text { abundance }\end{array}$ & $\begin{array}{l}\text { Contribution } \\
\text { to similarity }(\%)\end{array}$ \\
\hline $\begin{array}{l}\text { Phylum Chlorophyta } \\
\text { ( } 62 \% \text { average similarity) }\end{array}$ & $\begin{array}{l}16: 0 \\
18: 3 n-3 \\
18: 2 n-6 \\
18: 1 n-7 \\
16: 4 n-3\end{array}$ & $\begin{array}{r}29.96 \\
20.42 \\
7.24 \\
7.15 \\
6.44\end{array}$ & $\begin{array}{r}36 \\
26 \\
7 \\
6 \\
4\end{array}$ \\
\hline $\begin{array}{l}\text { Class Phaeophyceae } \\
\text { ( } 70 \% \text { average similarity) }\end{array}$ & $\begin{array}{l}16: 0 \\
18: 1 n-9 \\
20: 4 n-6 \\
20: 5 n-3 \\
18: 4 n-3\end{array}$ & $\begin{array}{l}21.85 \\
14.15 \\
10.53 \\
11.73 \\
10.89\end{array}$ & $\begin{array}{l}25 \\
14 \\
11 \\
11 \\
10\end{array}$ \\
\hline $\begin{array}{l}\text { Phylum Rhodophyta } \\
\text { ( } 66 \% \text { average similarity) }\end{array}$ & $\begin{array}{l}16: 0 \\
20: 5 n-3 \\
18: 1 n-9 \\
20: 4 n-6 \\
14: 0\end{array}$ & $\begin{array}{r}34.66 \\
30.34 \\
7.37 \\
8.40 \\
4.45\end{array}$ & $\begin{array}{r}44 \\
31 \\
7 \\
5 \\
5\end{array}$ \\
\hline $\begin{array}{l}\text { Phylum Dinoflagellata } \\
\text { ( } 48 \% \text { average similarity) }\end{array}$ & $\begin{array}{l}16: 0 \\
18: 1 n-9 \\
22: 6 n-3 \\
20: 5 n-3 \\
18: 0\end{array}$ & $\begin{array}{r}26.92 \\
13.70 \\
13.14 \\
10.39 \\
7.49\end{array}$ & $\begin{array}{r}42 \\
15 \\
12 \\
10 \\
7\end{array}$ \\
\hline $\begin{array}{l}\text { Class Bacillariophyceae } \\
\text { (65\% average similarity) }\end{array}$ & $\begin{array}{l}16: 1 n-7 \\
16: 0 \\
20: 5 n-3 \\
14: 0 \\
16: 3 n-4\end{array}$ & $\begin{array}{r}25.97 \\
19.42 \\
15.19 \\
13.51 \\
6.14\end{array}$ & $\begin{array}{r}33 \\
21 \\
15 \\
14 \\
4\end{array}$ \\
\hline $\begin{array}{l}\text { Phylum Tracheophyta } \\
\text { (56\% average similarity) }\end{array}$ & $\begin{array}{l}16: 0 \\
18: 3 n-3 \\
18: 2 n-6 \\
18: 1 n-9 \\
18: 0\end{array}$ & $\begin{array}{r}26.08 \\
30.32 \\
13.88 \\
4.50 \\
3.48\end{array}$ & $\begin{array}{r}38 \\
34 \\
12 \\
4 \\
4\end{array}$ \\
\hline
\end{tabular}

Macroalgae are rich in PUFAs, and contain especially high concentrations of n-6 PUFAs as compared with microalgae (Dalsgaard et al. 2003). Red algae typically contain a high concentration of 20:5n-3 (as high as $67 \%$ in Adouinella purpurea, Graeve et al. 2002) and moderate levels of 20:4n-6, 18:1n-9, and 16:1n-7 (Vaskovsky et al. 1996, Graeve et al. 2002, Li et al. 2002). Rhodophyta is the oldest macroalgal lineage, and dominance of $\mathrm{C}_{20}$ PUFAs is considered an ancestral characteristic (Graeve et al. 2002). Green algae contain a higher concentration of $\mathrm{C}_{18}$ PUFAs (18:3n-3, 18:2n-6, 18:4n-3) and lower levels of $\mathrm{C}_{20}$ PUFAs than other macroalgae (Vaskovsky et al. 1996, Khotimchenko et al. 2002, Li et al. 2002). Certain green algae also contain high levels of $16: 4 n-3$ (10 to $20 \%$ in the order Ulvales; Fleurence et al. 1994, Vaskovsky et al. 1996, Khotimchenko et al. 2002). Green algae represent the most modern macroalgal lineage, and their FA composition is most similar to that of higher plants, which are generally dominated by $\mathrm{C}_{18}$ PUFAs (Graeve et al. 2002). In our analysis, green and red macroalgae are distinguished mainly by 20:5n-3, which is more abundant in red algae, and 18:3n-3, which is more abundant in green algae (Table 3 ). Brown algae are characterized by relatively high concentrations of 20:5n-3, 20:4n-6, 18:1n-9, and 18:4n-3, with slightly lower concentrations of $18: 2 \mathrm{n}-6$ and $18: 3 \mathrm{n}-3$ (Vaskovsky et al. 1996, Graeve et al. 2002, Khotimchenko et al. 2002, Li et al. 2002). This mixed FA composition supports the intermediate phylogenetic position of the Phaeophyta (brown algae) between the older Rhodophyta (red algae) and more modern Chlorophyta (green algae; Graeve et al. 2002). SIMPER analysis showed that the FAs that contribute most to differences between brown and green macroalgae are 18:3n-3 (more abundant in green algae) and 18:1n-9 (more abundant in brown algae). Brown and red macroalgae are distinguished by 20:5n-3 and 16:0, which are more abundant in red algae, and by 18:4n-3, 20:4n-6, and 18:1n-9, which are more abundant in brown algae (Table 3 ). Considerable seasonal variability in FA composition has been found in macroalgae (Honya et al. 1994, Nelson et al. 2002), and sampling for FA characterization ideally should span all seasons to capture this variation. 


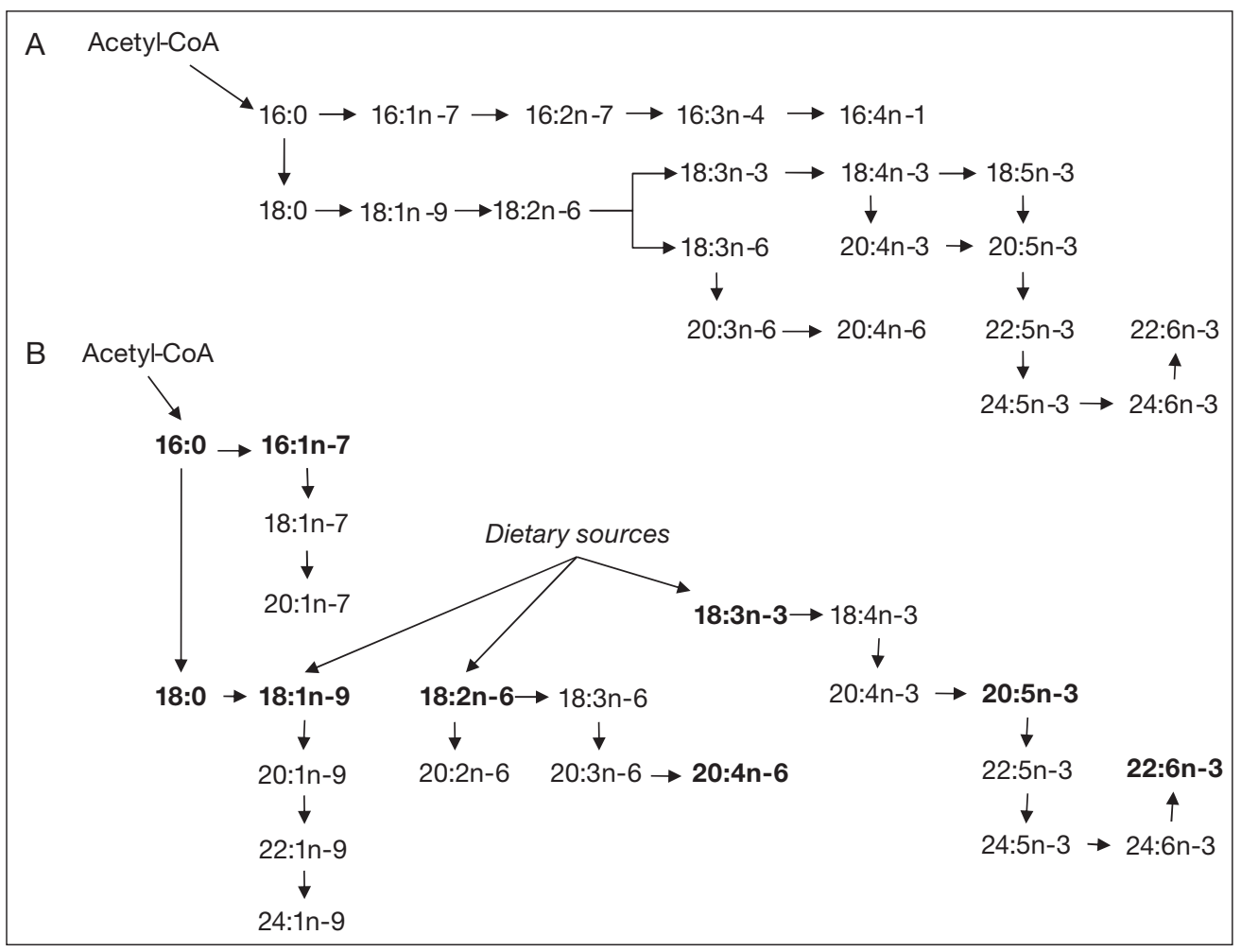

Fig. 2. Major fatty acid (FA) biosynthetic pathways in (A) plants and algae and (B) animals. FAs shown in bold in (B) tend to accumulate at relatively high concentrations in animal tissues. Horizontal arrows represent desaturation, downward vertical arrows represent 2-carbon chain elongation, and upward vertical arrows represent $\beta$-oxidation. Modified after Gurr et al.

(2002) and Bergé \& Barnathan (2005)

\section{Vascular plants}

Vascular plants contribute to nearshore benthic food webs through direct consumption by grazers and via detrital pathways (Meziane et al. 1997, Hall et al. 2006). As in green algae, PUFAs in vascular plants consist mainly of 18:2n-6 and 18:3n-3 (Dalsgaard et al. 2003). Saturated, long-chain FAs (LCFAs) with an even number of carbon atoms $\left(\geq C_{22}\right)$ are found in the waxy leaf cuticle of higher plants; along with 18:2n-6 and 18:3n-3, these LCFAs serve as indicators of vascular plant matter in sediments and suspended organic matter (Canuel et al. 1995, Budge et al. 2001). LCFAs have also been used as trophic markers for mangroves and halophytes in benthic invertebrates (Meziane et al. 1997, Meziane \& Tsuchiya 2000, 2002), but they are not assimilated by all consumers and may be of limited use as tracers in some food webs (Hall et al. 2006). SIMPER analysis showed that vascular plants differ from green algae in having higher relative abundance of 18:3n-3, 18:2n-6, and LCFAs (Table 3).

\section{Marine bacteria}

Both autotrophic and heterotrophic bacteria play an important role in many benthic food webs, as food sources for deposit and suspension feeders, and as endosymbionts of invertebrates (Kharlamenko et al. 1995, Pond et al. 1997, 2002, Meziane \& Tsuchiya 2002, Howell et al. 2003, McLeod \& Wing 2009). FA composition of cyanobacteria is generally dominated by $16: 0$ and 14:0, with lower concentrations of 18:0, 16:1n-9, and 18:1n-9 (Carpenter et al. 1997). FA biosynthesis in heterotrophic bacteria produces oddnumbered and branched FAs such as 15:0, 17:0, 15:1, $17: 1$, and iso- and anteiso-branched SFAs (Dalsgaard et al. 2003). These FAs, along with $16: 1 \mathrm{n}-7$ and $18: 1 \mathrm{n}$ 7 , are typically dominant in bacterial FA composition and are used as tracers for the contribution of heterotrophic bacteria to sediments, suspended organic material, and animal diets (Kharlamenko et al. 1995, Meziane \& Tsuchiya 2002, Dalsgaard et al. 2003). Production of PUFAs is relatively rare among bacteria, although PUFA synthesis has been shown in cold-water and deep-sea bacteria (Nichols et al. 
1993, Russell \& Nichols 1999). Relative proportions of various bacterial FAs are indicative of different taxonomic groups of bacteria (Sargent et al. 1987, Colaço et al. 2007; our Appendix 1), and have been used to examine microbial community structure in marine sediments (Parkes \& Taylor 1983, Gillan \& Hogg 1984, McLeod \& Wing 2009).

\section{CONTROLLED FEEDING STUDIES}

Controlled feeding studies in a laboratory setting can further our understanding of how FAs are transferred from food to consumer, which FAs are catabolized or excreted, and how specific FAs affect consumer growth and physiology. Field studies in which diet is inferred from FAs present in consumers generally assume that FAs are transferred from food to consumer with minimal modification. This is a reasonable assumption in some taxa; for example, mammalian predators have a very limited capacity to alter dietary FAs (Budge et al. 2006). However, because benthic invertebrates have a greater ability to modify dietary FAs (Dalsgaard et al. 2003, Bell \& Tocher 2009), controlled feeding studies should be employed before using FAs as dietary tracers in field studies. Many controlled feeding studies of benthic organisms have been undertaken for aquaculture-related purposes, such as maximizing growth, reproduction, or larval survival (e.g. Glencross \& Smith 1999, Castell et al. 2004, Calado et al. 2005). Diets in such studies often include feeds with high concentrations of specific FAs, making it possible to isolate the effects of FAs of interest (Castell et al. 2004, Calado et al. 2005). However, the diets used in such studies typically bear little resemblance to natural diets, and as such the results generally are not useful for determining the diets of animals in the wild. More controlled feeding studies using natural diets are required for validation of indicator FAs and to improve understanding of biosynthesis and selective retention. These studies can also help to quantify variation in FAs among tissue types, life history stages, and reproductive phases, as these factors can have a significant impact on FA composition (Hughes et al. 2006, Mateos et al. 2010).

\section{FA transfer}

Controlled feeding studies have identified FAs that transfer reliably from food to consumer. These FAs may be useful as indicators for identifying certain food sources in the diets of consumers if their concen- trations are found to be (1) significantly higher in 1 food source than others and (2) significantly higher in consumers of the food source of interest as compared to consumers of other foods. Most studies that have demonstrated FA transfer in benthic invertebrates have used artificial diets enriched with high concentrations of certain FAs (Castell et al. 2004, Suprayudi et al. 2004, Liu et al. 2007).

The results of comparisons among natural diets are likely more applicable to ecologists seeking tracers for use in field studies than are aquaculture-focused studies comparing artificial diets, but controlled feeding studies comparing natural foods are relatively few. Indicator FAs for rotifers, diatoms, dinoflagellates, kelps, and green algae have been identified in their various invertebrate consumers (D'Souza \& Loneragan 1999, Shin et al. 2008, Kelly et al. 2009). However, when sea urchins Strongylocentrotus droebachiensis were fed 4 different algal diets, no indicators distinguished sea urchins among diet treatments (Kelly et al. 2008).

Tracking changes in FA composition over time during a controlled feeding experiment may also be useful for validating FA indicators for a diet of interest. When sea urchins Strongylocentrotus droebachiensis were switched from kelp to a grain-based diet, kelp indicators decreased, and indicators for the artificial diet increased in sea urchin tissues (Liyana-Pathirana et al. 2002). Both mangrove leaves and the tissues of crabs Parasesarma erythodactyla fed these leaves contained high levels of 18:2n-6 and 18:3n-3 (Hall et al. 2006). A feeding/starving regimen provided further support for these FAs as dietary indicators: levels of both FAs increased when crabs were fed mangrove leaves, and decreased during starvation periods. 18:3n-3 had similar indicator properties when tissues of $P$. erythodactyla were fed to another crab (Portunus pelagicus). However, both FAs are common in primary producers and may be of limited use in field studies (Hall et al. 2006).

\section{FA biosynthesis and selective retention}

Many invertebrate taxa possess active elongase and desaturase enzymes that enable them to significantly modify dietary FAs (Spychalla et al. 1997, D'Souza \& Loneragan 1999, Bell et al. 2001, Hall et al. 2006). Crabs Parasesarma erythodactyla and Portunus pelagicus and larval prawns Penaeus spp. synthesized highly unsaturated FAs (HUFAs) when these were absent from their diets, suggesting biosynthesis from dietary precursors (D'Souza \& Lonera- 
gan 1999, Hall et al. 2006). Bell et al. (2001) used a radio-labeled diet to show that the sea urchin Psammechinus miliaris can convert 18:3n-3 to 20:5n-3, even when 20:5n-3 is present in the diet, but that the rate of conversion is very slow. Because marine fish and mammals cannot convert $18: 2 n-6$ and $18: 3 n-3$ to the HUFAs 20:4n-6, 20:5n-3, and 22:6n-3, and must obtain these FAs from their diets, biosynthesis by invertebrates may represent an important link in marine food webs (Sargent et al. 1999, Hall et al. 2006).

Products of biosynthesis may be useful as dietary indicators if there is a clear relationship between levels of the precursor FAs in the food and the product in the consumer. Sea urchins Strongylocentrotus droebachiensis fed artificial diets rich in 18:1n-9 had high concentrations of both $18: 1 \mathrm{n}-9$ and its elongation product 20:1n-9 (Castell et al. 2004). Levels of HUFAs in sea urchins were directly related to levels of $\mathrm{C}_{18}$ precursor FAs in HUFA-deficient artificial diets (Castell et al. 2004). The use of products of FA biosynthesis as dietary indicators merits further research, as these may prove useful in field studies where few dietary indicator FAs are transferred directly to consumer tissues.

Either biosynthesis or selective retention may be postulated when consumer tissues contain higher concentrations of certain FAs than does their food (Castell et al. 2004). Controlled feeding studies of larval and adult sea urchins have found relatively high concentrations of HUFAs and $\mathrm{C}_{20}$ and $\mathrm{C}_{22}$ MUFAs in sea urchin tissues (5 to $18 \%$ ) when these were present only in trace amounts $(<0.1 \%)$ in their diets (Castell et al. 2004, Liu et al. 2007, Kelly et al. 2008). The magnitude of the increase between diet and tissues, in addition to the presence of $\mathrm{C}_{18}$ precursors in the diets, suggests biosynthesis rather than selective retention by sea urchins. In contrast, juvenile shrimp Lysamata seticaudata contained higher HUFA concentrations than did their food, but the very low concentrations of $\mathrm{C}_{18}$ precursor FAs in their food suggested selective retention rather than biosynthesis (Calado et al. 2005). Both biosynthesis and selective retention of HUFAs are likely to occur only when the diet is deficient in these (Iverson 2009). For example, Cook et al. (2000) found that sea urchins Psammechinus miliaris selectively retained HUFAs 20:4n-6 and 20:5n-3 when fed salmon feed pellets that were deficient in these, but not when fed kelp, their natural diet, which contained higher concentrations of both HUFAs. FA data from controlled feeding experiments should be carefully examined for evidence of biosynthesis and selective retention to distinguish FAs affected by these processes from those that are directly deposited from diet.

\section{Egested FAs}

Consumers may egest certain FAs rather than assimilating them directly or after modification. Mangrove leaves contained 17 to $24 \%$ LCFAs (24:0, 26:0, and 28:0), but tissues of crabs Parasesarma erythodactyla fed mangrove leaves did not contain these FAs (Hall et al. 2006). However, feces of $P$. erythodactyla contained over $15 \%$ LCFAs, suggesting that the crabs may be unable to metabolize these FAs (Hall et al. 2006). These results highlight the need for controlled feeding studies before FAs are used as tracers in field studies: the lack of LCFAs in tissues of $P$. erythodactlya could otherwise appear to indicate that these crabs do not feed on mangrove leaves. Fecal pellets of deposit-feeding fiddler crabs Uca vocans and Scopimera globosa also contained LCFAs that were absent from their tissues (Meziane et al. 2002). These feces also contained lower levels of indicator FAs for bacteria and diatoms than did tissues and sediments, suggesting that the crabs effectively assimilated diatoms and bacteria but not mangrove leaves (Meziane et al. 2002). Comparisons of FA profiles of consumer feces to those of food and consumer tissues may provide valuable information in other benthic systems and should be included in controlled feeding studies.

\section{FA ANALYSIS OF BENTHIC FOOD WEBS}

FA analysis has been used in field studies to address a variety of questions related to trophic structure in benthic habitats. One relatively common use is to infer diet from consumer FAs. However, predicting consumer diets based on a few FAs can be problematic, since most marine FAs are ubiquitous and therefore rarely indicate the presence of a specific food item. Use of a single or few FAs can also be misleading in that these FAs could be obtained by consuming a primary producer, or by preying on a consumer of that primary producer (Budge et al. 2006). FAs are frequently used as tracers in field studies without considering the role of consumer metabolism, even though this may play a significant role in determining consumer FA composition. Field studies that use tracers validated in controlled feeding studies are rare (Cook et al. 2000), but such studies are important because they allow comparison between consumers fed a single diet and wild-caught animals that likely consumed a mixed diet, and provide some indication of which FAs are affected by biosynthesis or selective retention. Ideally, field stud- 
ies should employ multivariate analyses to examine overall patterns and to identify FAs that are important in separating groups in addition to univariate comparisons.

FAs are useful in habitats where direct observation would pose significant challenges, such as the deep sea (Howell et al. 2003, Drazen et al. 2009). FA tracers are also used to determine the fate of primary production, especially in habitats where the dominant primary producer is not directly consumed by the dominant herbivores (Meziane \& Tsuchiya 2000, Kharlamenko et al. 2001). Other field studies have employed FA analysis to address ecological questions about how animal diets vary with habitat, season, and anthropogenic effects (Takagi et al. 1980, Hughes et al. 2005, Fernandez-Jover et al. 2007).

\section{Deep sea and hydrothermal vent food webs}

Deep sea food webs are especially well-suited to study using FA analysis because direct observation is difficult at depth, and food webs are relatively simple because of the limited number of primary producers. Studying the diet of deep sea species using more direct methods is problematic because the pressure changes experienced as animals are brought to the surface frequently causes regurgitation or stomach eversion, precluding analysis of stomach contents (e.g. sea stars, Howell et al. 2003; macrourid fishes, Drazen et al. 2009). Relative abundances of several diet-derived FAs varied among 7 species of deep sea holuthurians from the northeast Atlantic, suggesting a diversity of feeding modes or niches (Ginger et al. 2000). Deep sea holothurians and ophiuroids from the northeast Pacific were distinguished by the higher proportions of algal-derived HUFAs in the deposit-feeding holothurians and by copepodderived MUFAs in the omnivorous ophiuroids (Drazen et al. 2008a). When 8 species of deep-sea sea stars from the northeast Atlantic were classified according to their overall FA composition, their categories corresponded with their known feeding types: suspension feeders contained higher proportions of indicator FAs of diatoms, dinoflagellates, and copepods; and mud-ingesting sea stars contained higher proportions of bacterial FAs (Howell et al. 2003). Each of the 3 predator-scavenger species had a distinct FA composition, indicating specialization on (1) benthic invertebrates and foraminifera, (2) microinfauna, and (3) echinoderms (Howell et al. 2003). These studies demonstrate the utility of FA analysis in classifying benthic consumers (particularly those that are difficult to sample and observe in situ) into various trophic groups.

Chemoautotrophic bacteria provide the major food source for invertebrate communities at deep sea hydrothermal vents, and their characteristic FA profile allows these bacteria to be traced through the food web. In deep sea habitats, 16:1n-7 and 18:1n-7 indicate bacterial food sources, especially when $20: 1 \mathrm{n}-7$ and $22: 1 \mathrm{n}-7$ are present and the microalgal indicator FAs 20:5n-3 and 22:6n-3 are absent (BenMlih et al. 1992). These bacterial indicator FAs have been found in several hydrothermal vent invertebrates including deep sea mussels Bathymodiolus thermophilus (Ben-Mlih et al. 1992, Phleger et al. 2005), shrimp Rimicaris exoculata (Pond et al. 1997), clams Calyptogena pacifica (Allen et al. 2001), and tubeworms Riftia pachyptila (Phleger et al. 2005). Colaço et al. (2007) classified invertebrates from deep hydrothermal vents at the Mid-Atlantic Ridge into 2 groups based on their overall FA composition: (1) mussels, their commensal polychaetes, and whelks, which all contained a higher proportion of branched n-7 FAs, indicating a reliance on sulfide-reducing bacteria; and (2) shrimp and crabs, which contained a higher proportion of n-7 MUFA and non-methyleneinterrupted (NMI) FAs, indicating a reliance on sulfate-oxidizing bacteria. The deposit-feeding polychaete Amathys lutzi contained indicator FAs of both types of bacteria, indicating that it feeds non-selectively (Colaço et al. 2007). In addition to bacterial FAs, shrimp Alvinocaris markensis from the Juan de Fuca Ridge contained high proportions of HUFAs 20:5n-3 and 22:6n-3. These HUFAs are often considered markers of phytodetritus (i.e. diatoms and dinoflagellates), but 22:6n-3 in particular may also indicate a scavenging diet, and appendages of $A$. markensis are adapted for scavenging (Pond et al. 1997). Low proportions of $20: 5 n-3$ and $22: 6 n-3$ in hydrothermal vent mussels $B$. thermophilus (BenMlih et al. 1992) and clams C. pacifica (Allen et al. 2001) are likely to be photosynthetically-derived and acquired by filter feeding. Tubeworms Ridgeia piscesae and Protis hydrothermica from hydrothermal vents were rich in bacterial indicator FAs, but also in 20:5n-3 and 20:4n-6 (Pond et al. 2002). R. piscesae, which relies entirely on bacterial endosymbionts for nutrition, has the enzymes required to synthesize these HUFAs from bacterially derived $\mathrm{C}_{18}$ precursors (Pond et al. 2002). This underscores the importance of understanding the biosynthetic capabilities of animals before attempting to infer diet from FA composition.

Like their deep-water counterparts, shallow hydrothermal vent systems are host to chemoautotrophic 
bacteria (Kharlamenko et al. 1995). However, animals in shallow vent systems have access to a wider variety of potential food sources, including planktonic diatoms, particulate organic matter, microbial mats, sediments, and macrophytes, and may therefore have more complex trophic pathways. Based on their overall FA profiles, 16 consumer taxa at a shallow hydrothermal vent off the Kurile Islands in the northwest Pacific were classified into 7 clusters that corresponded generally with their feeding modes. Suspension feeders had high levels of the diatom indicator 20:5n-3, while carnivorous polychaetes and corals clustered together in multivariate space and had high levels of 22:6n-3. Sea cucumbers Eupentacta pseudoquinquesemita and Psolus spp. had high bacterial FA concentrations, which point to deposit feeding, and also relatively high concentrations of 20:5n-3, suggesting diatoms as a likely food source. These species are suspension feeders, so the high concentration of 20:5n-3 was expected, and dissection of gill tissues revealed symbiotic bacteria (rather than the microbial mat) as the source of bacterial FAs (Kharlamenko et al. 1995).

\section{Polar food webs}

FA analysis of benthic fauna in polar habitats has improved our understanding of their trophic interactions. In the Arctic, suspension-feeding brittle stars were rich in indicator FAs for diatoms (Graeve et al. 1997). Benthic decapod crustaceans in the Arctic contained high concentrations of both diatom and carnivory indicators, suggesting that their prey consumed diatoms (Graeve et al. 1997). FA profiles of 6 species of Antarctic amphipods corresponded with their feeding modes: for example, the grazer Oradarea edentata was rich in the macroalgal indicator 20:4n-6 (Graeve et al. 2001).

Indicator FAs have also been used to identify diets of higher consumers in polar food webs. In the Antarctic, FA compositions of benthic icefishes Dolloidraco longedorsalis and Bathydraco marri were similar to that of their benthic invertebrate prey in that all were rich in diatom and carnivory indicator FAs (Hagen et al. 2000). Copepod indicators (20:1 and 22:1 MUFAs) comprised $<5 \%$ of total FAs in benthic icefishes, as compared with 10 to $15 \%$ in pelagic species (Hagen et al. 2000). In the Arctic, FA composition of Pacific walruses Odobenus rosmarus was distinct from that of bearded seals Erignathus barbatus based on the higher ratio of n-7 to n-9 isomers of $\mathrm{C}_{18}-\mathrm{C}_{22}$ MUFAs in walruses (Budge et al. 2007).
A high n-7 to $n-9$ ratio is characteristic of benthic mollusks, which are thought to be the major prey of walruses. The 2 species also differed in the composition of their NMI FAs, suggesting that levels of individual NMI FAs may be useful as species-specific markers for certain benthic invertebrates in the diets of higher consumers (Budge et al. 2007).

\section{Estuarine food webs}

Estuarine habitats support relatively diverse faunal assemblages, but few of the resident species directly consume the dominant macrophytes, such as mangroves and seagrasses (Meziane \& Tsuchiya 2000, Kharlamenko et al. 2001). FA analysis has been used to trace the fate of these primary producers and to compare the relative contribution of mangrove and seagrass material to consumer diets with that of other food sources such as macroalgae, diatoms, dinoflagellates, zooplankton, and bacteria. The diversity of potential food sources in these habitats requires that their FAs be characterized before attempting to infer consumer diets, and the overlap in indicator FAs among common food sources (Appendix 1) points to the need for multivariate analysis rather than interpretation of single FAs. Many of the field studies using FAs to identify diets of estuarine consumers have relied entirely on comparisons between consumers and their potential food sources (e.g. Kharlamenko et al. 2001, Alfaro et al. 2006), without controlled feeding studies that demonstrate trophic transfer of certain indicator FAs.

Based on indicator FAs present in consumer tissues, Kharlamenko et al. (2001) concluded that most animals in a seagrass bed in the Sea of Japan consumed seagrass as detritus or suspended particulate matter, and that diet of deposit feeders was more varied than that of grazers. Several mollusks in the study contained relatively high levels of 20:4n-6, which was attributed to consumption of fungi, even though fungi were not analyzed and 20:4n-6 was found only in very low levels in sediments and suspended particulate matter. Biosynthesis of 20:4n-6 from its precursor 18:2n-6 may have been a more likely source of this FA, and has been demonstrated in controlled feeding studies of the scallop Pecten maximus (Soudant et al. 1996).

Most consumers in a tropical mangrove- and seagrass-dominated estuary in northern New Zealand utilize a variety of food sources including mangrove leaves, seagrass, microalgae, a brown macroalga, zooplankton, and bacteria (Alfaro et al. 2006). Alfaro et al. (2006) interpreted the presence of 18:3n-3 con- 
servatively, since it was present in both seagrass and mangrove leaves. This relatively cautious approach to interpreting FA indicator data is particularly appropriate when controlled feeding data are not available for consumers, and therefore their capacity for FA modification is unknown. Data from Alfaro et al. (2006) show evidence of biosynthesis or selective retention of PUFAs by some consumers. For example, 20:5n-3 accounted for $17.7 \%$ of FAs in the shrimp Palaemon affinis, while the highest concentration of this FA in any potential food source was $6.0 \%$ in sediment. Many invertebrates are capable of synthesizing 20:5n-3 using 18:3n-3 as a precursor (e.g. crab Parasesarma erythodactyla, Hall et al. 2006; sea urchin Strongylocentrotus droebachiensis, Castell et al. 2004). Relative abundance of $18: 3 \mathrm{n}-3$ in primary producers ranged from $3.0 \%$ in the brown macroalga Hormosira banksii to $27.4 \%$ in seagrass, but its maximum abundance in consumers was $2.1 \%$. This suggests that 18:3n-3 was usually catabolized by consumers and was probably not useful as an indicator, although this was not considered by Alfaro et al. (2006). This underscores the need for controlled feeding studies to distinguish FAs that are reliable indicators from those that are affected by consumer metabolism.

Food webs of temperate estuaries are similar to those in the tropics in that most consumers are trophic generalists, and most of the biomass of dominant primary producers enters the detrital food web rather than being directly grazed (Meziane et al. 1997, Richoux \& Froneman 2008). Although 10 food sources in a temperate South African estuary had distinct FA compositions, relatively few indicators for these food sources were useful in distinguishing among 14 consumer species (Richoux \& Froneman 2008). Multivariate analyses of FA composition separated consumers into 2 general groups based on dominance of either dinoflagellates or benthic diatoms in their diets (Richoux \& Froneman 2008). Benthic diatoms appear to play an important role in temperate estuarine food webs: the diatom indicators 16:1n-7 and 20:5n-3 comprise significant proportions of total FAs in sediments and animals, but not in suspended material (Meziane et al. 1997, Richoux \& Froneman 2008).

\section{Rocky subtidal food webs}

Relatively few studies have used FAs to analyze rocky subtidal food webs, and a majority of these studies have focused on identifying diets of sea urchins. FA composition of sea urchins Strongylocen- trotus droebachiensis from a kelp bed off the Atlantic coast of Nova Scotia, Canada, differed from that of sea urchins from nearby coralline algae-dominated barrens (Takagi et al. 1980). Most notably, both kelp and sea urchins from the kelp bed were rich in 20:4n-6, while sea urchins from barrens contained a higher proportion of n-3 PUFAs. Intertidal and subtidal populations of the sea urchin Psammechinus miliaris off the west coast of Scotland differed in their FA composition, but these differences were not consistent between sites, suggesting that sea urchin diets are variable (Hughes et al. 2005). FA composition was not reported for the dominant macroalgae, but dominant taxa in the intertidal (fucoid algae) and subtidal (laminarian kelp) zones may not have been sufficiently distinct in their FA composition to allow differentiation at the next trophic level. Intertidal sea urchins at 1 site contained a higher concentration of the carnivory indicator 22:6n-3, suggesting that invertebrate prey contributed to their diet (Hughes et al. 2005). As in estuarine food webs, the utility of FAs as dietary tracers in the rocky subtidal zone is limited because of the diversity of potential food sources and lack of unique markers. In both systems, it appears that FAs should be used primarily for classifying consumers into broad dietary groups unless controlled feeding studies have been used to verify the trophic transfer of specific FAs.

\section{Aquaculture effects on food webs}

The effects of fish farms on animal diets and trophic interactions are well-suited to FA analyses because fish feed tends to contain indicator FAs that distinguish it from other benthic food sources. Sea urchins Psammechinus miliaris living under a salmon pen off the west coast of Scotland contained high concentrations of 22:6n-3, which is a major constituent FA of the salmon feed (Cook et al. 2000). Sea urchins fed salmon feed pellets in the laboratory also contained high levels of 22:6n-3, confirming that 22:6n-3 is a valid indicator for this salmon feed in sea urchins. FAs 18:4n-3 and 20:4n-6 were similarly validated as indicators for kelp and were elevated in sea urchins from kelp-dominated intertidal sites (Cook et al. 2000). Invasive amphipods Caprella mutica collected from salmon pens, mussel longlines, and an artificial reef contained relatively high concentrations of 20:5n-3, 22:6n-3, and 18:1n-9, indicating an omnivorous diet including animal material and diatoms (Cook et al. 2010). Wild Mediterranean horse mackerel Trachurus mediterraneus that aggregated near fish pens off the south-east coast of Spain had 
similar FA composition to feed pellets, in contrast to control populations distant from fish farms (Fernandez-Jover et al. 2007). The use of indicator FAs to detect non-native food sources in consumer diets is a promising application of FAs in benthic systems.

\section{STATISTICAL ANALYSIS OF FA DATA}

The large size of most FA datasets requires that overall patterns among samples be examined using a multivariate statistical approach. Similarity-based techniques may be most appropriate for FA data because they have fewer assumptions regarding data structure and can be used with small sample sizes. Univariate statistical methods can be used in conjunction with multivariate analyses to compare levels of individual tracer FAs among consumers and/or food sources, but care should be taken to minimize Type I errors associated with multiple comparisons. While a wide variety of statistical techniques could potentially be applied to FA data, we briefly review those that are most commonly used.

\section{Multivariate statistics}

Multivariate analysis of variance (MANOVA) and discriminant function analysis (DFA) are used to examine differences in overall FA composition among a priori groups of samples, e.g. different species (Budge et al. 2002), functional groups (Piché et al. 2010), or consumers on different diets in a controlled feeding study (Navarro et al. 1997). MANOVA is used to test for significant differences in overall FA composition among groups of samples by examining whether mean differences among groups could have occurred by chance. DFA calculates the combination of FAs that produces maximum multivariate distance among groups by creating uncorrelated linear equations of the original FAs. Scores of samples on the resulting discriminant functions can be plotted to reveal relationships among samples. Interpretation of DFA results is relatively simple, and FAs that are most important in separating groups along each function can usually be identified (Navarro et al. 1997, Budge et al. 2006). DFA can also be used to classify new samples into trophic groups based on FA composition (Hair et al. 2006).

Principal component analysis (PCA) is used as an exploratory technique to examine relationships among samples, and to simplify large FA datasets. PCA reduces large numbers of variables to a few components that represent most of the variance in the data by combining correlated FA into new components. This allows identification of FAs that contribute most to separation among observed groups and FAs that are highly correlated (Budge et al. 2006). Tracer FAs for food sources of interest may be useful for interpreting PCA results where FAs that contribute to discriminating groups are also tracers. The scores of each sample on the first 2 to 3 principal components can be plotted to visualize relationships among samples. PCA has been used in benthic habitats to compare FA signatures of consumers to their potential food items (Guest et al. 2008, Drazen et al. 2009) and to classify consumers by feeding mode (Colaço et al. 2007, Drazen et al. 2008a, Richoux \& Froneman 2008).

MANOVA and DFA assume that the data are multivariate normal and the covariance matrices are homogeneous (Hair et al. 2006). The assumptions of PCA are somewhat less stringent, although multivariate normality is preferred and more samples than variables are required for reliable results (Hair et al. 2006). Proportional FA data require transformation to meet the assumption of multivariate normality (Budge et al. 2006). The log-ratio transformation, $x_{\text {trans }}=\ln \left(x_{i} / C_{\mathrm{r}}\right)$, where $x_{i}$ is a given FA expressed as percent of total FAs, and $C_{\mathrm{r}}$ is the percentage of a reference FA, has been recommended for FA data (Budge et al. 2006, Piché et al. 2010). The reference FA for this transformation should be one that is present regardless of diet, and is reliably quantified (Budge et al. 2006). The arcsine transformation is also commonly used for proportional data and may improve normality in some cases (Cook et al. 2000, Castell et al. 2004, Thurber 2007). The logit transformation may be more suitable alternative (Warton \& Hui 2011), but multivariate normality is difficult to achieve with large FA datasets, even after transformation (Budge et al. 2006). If normality is tested at all, it is usually for individual FAs (e.g. Shapiro-Wilk test), and not for the multivariate dataset (e.g. HenzeZirkler test). Additionally, to avoid heterogeneity of covariance, the number of variables in FA datasets usually must be reduced to $n-1$ where $n$ is the smallest number of samples in any group, and each group should contain at least 20 samples (Budge et al. 2006, Hair et al. 2006). The subset of FAs retained for analysis should include those that are generally obtained from diet rather than from biosynthesis by the consumer, and those that are tracers of potential food items (Iverson et al. 2004, Budge et al. 2006). However, the selection of FAs that are of dietary rather than biosynthetic origin is often difficult for 
benthic invertebrates because many species are capable of substantial FA biosynthesis (D'Souza \& Loneragan 1999, Cook et al. 2000, Castell et al. 2004, Calado et al. 2005, Hall et al. 2006), and FA metabolism for most species is not well-studied. The cost of obtaining an adequate number of samples for these techniques may be prohibitive, especially in studies that aim to describe a food web rather than the diet of one or a few consumers of interest. Statistical techniques with fewer assumptions regarding data structure may therefore be more practical for most studies of trophic relationships in benthic habitats.

Cluster-forming methods such as classification and regression trees (CART) and hierarchical clustering do not assume homogeneity of covariances or multivariate normal data, and more importantly, the number of independent variables (i.e. FAs) is not limited by sample size (Smith et al. 1997, Budge et al. 2006). CART uses FAs with the greatest variance to divide the samples into dichotomous groups. CART may be useful as an exploratory method because it does not require selection of a smaller subset of FAs; however, the algorithm may use FAs that are not biologically meaningful to create tree nodes (Budge et al. 2006). For example, 16:0 is ubiquitous because most organisms are capable of synthesizing it de novo, but its relative abundance varies among taxa. CART also does not provide any indication of overall relationships among samples (Budge et al. 2006). Hierarchical clustering uses the overall similarity between samples to either link them into increasingly large groups or divide them into dichotomous groups (Hair et al. 2006). It is similar to CART in that it is an exploratory method with few assumptions regarding data structure, but in hierarchical clustering the distances between groups in the resulting dendrogram represent their dissimilarity (Budge et al. 2006). Hierarchical clustering does not test whether groups are significantly different from each other; however, the similarity profile (SIMPROF) analysis in the PRIMER software package (Clarke \& Gorley 2006) can be applied to test whether each node of the dendrogram represents a statistically significant division (Clarke et al. 2008).

Similarity-based statistical techniques are especially useful for FA data because they do not require homogeneity of covariances or multivariate normality, can be used with a large number of variables, and include a variety of both exploratory and hypothesistesting methods (Clarke 1993). FA data are often used in similarity-based analyses without transformation to avoid giving artificial weight to FAs that are present in small quantities (Howell et al. 2003,
Hall et al. 2006, Kelly et al. 2008, 2009), but in most cases, analyses on untransformed data effectively only use abundant FAs. The data are used to calculate a triangular matrix of similarities (such as BrayCurtis similarity) between each pair of samples. MDS then uses the ranks of similarities in an iterative process to find the spatial arrangement of samples that best represents the relationships among them (Clarke \& Green 1988, Hair et al. 2006). MDS is an exploratory analysis that does not take into account any a priori groups and so can be used to classify consumers with unknown diets (Howell et al. 2003, Guest et al. 2008) as well as to look for spatial (Hughes et al. 2005, Fernandez-Jover et al. 2007) and temporal (Wai et al. 2008) differences in overall consumer FA composition. It has also been used to analyze the results of controlled feeding studies, both for comparing overall FA composition of animals on different diets (Kelly et al. 2008, 2009) and for tracking changes to FA composition over time (Hall et al. 2006). While MDS provides a valuable visual representation of relationships among samples, an additional technique is necessary for hypothesis testing. Analysis of similarity (ANOSIM) is a non-parametric, similarity-based analogue to MANOVA that tests for differences in overall FA composition through permutations of the rank similarity matrix (Clarke 1993). ANOSIM is frequently used in conjunction with MDS, both for comparing a priori groups and for testing whether clusters observed in the MDS plot differ significantly from each other, and for performing pairwise comparisons among groups (Hughes et al. 2005, Hall et al. 2006, Kelly et al. 2008, 2009, Wai et al. 2008). The ANOSIM R statistic is a measure of similarity between groups on a scale of 0 to 1 : values between 0.5 and 0.75 indicate that groups are different, but have some degree of overlap, while R $>0.75$ indicates well-separated groups (e.g Jaschinski et al. 2011). Large sample sizes in ANOSIM may result in significant p-values even when groups are not wellseparated, so the R-value should be reported. However, ANOSIM is best used for 1-way tests (e.g. 1 species on different diets) and not for more complicated study designs (e.g. multiple species on different diets), as it does not calculate the proportion of variance attributable to each factor or test for interactive effects. Permutational multivariate analysis of variance (PERMANOVA) is a 'semi-parametric' MANOVA analogue that allows analysis of factorial and nested designs (Anderson 2001, 2005). PERMANOVA may therefore be better suited than ANOSIM for analysis of some FA data (e.g. FernandezJover et al. 2007, Crawley et al. 2009, Kelly et al. 
2012). ANOSIM, MDS, and PERMANOVA are available in the PRIMER software package (Clarke \& Gorley 2006).

While it is important to understand relationships among the overall FA compositions of samples in any study, the individual FA driving overall patterns may also be of interest. In studies of benthic food webs, both the characteristic FAs of potential food sources and the FAs contributing most to differences among consumer species or feeding groups can be informative. SIMPER analysis measures similarity between each pair of samples and calculates average similarity within groups and dissimilarity between groups, and examines the contribution of each FA to average similarity (Clarke 1993, Clarke \& Gorley 2006). SIMPER results can be used to identify potential indicator FAs. For example, 22:6n-3 had the highest contribution to dissimilarity between horse mackerel Trachurus mediterraneus collected from reference areas and near fish farms: reference fish were rich in 22:6n3 as compared with fish associated with fish farms (Fernandez-Jover et al. 2007). Where FAs identified by SIMPER are known indicators of specific food sources, the results can indicate diet of consumers. In the previous example, 22:6n-3 was an indicator for juvenile fish and cephalopods, which were the likely prey of reference fish (Fernandez-Jover et al. 2007). In deep-sea sea stars, FA composition of suspension feeders was characterized by copepod indicator FA 20:1n-9 as well as the phytoplankton indicators 20:5n-3 and 22:6n-3, which Howell et al. (2003) also attributed to feeding on copepods.

\section{Univariate statistics}

Although multivariate statistical methods should be used to analyze most FA datasets, the additional use of univariate tests on tracer FAs is appropriate following a finding of significant differences among groups using multivariate procedures. Univariate procedures such as analysis of variance (ANOVA) are commonly used for testing whether the concentration of a single FA differs among groups of samples, and several such comparisons may be performed on a single dataset if $\alpha$ is adjusted (e.g. using Bonferroni correction). ANOVA is commonly used in field studies to compare levels of specific FAs in organic material or animals among sampling locations (Cook et al. 2000, Alfaro et al. 2006, Meziane et al. 2006), or seasons (Bachok et al. 2003, Meziane et al. 2006), and among consumer species (Kharlamenko et al. 2001, Alfaro et al. 2006, Meziane et al.
2006). However, there are often several possible sources for a given indicator FA found in a consumer, and ecological knowledge and common sense should be applied in their interpretation. If available, information from a controlled feeding study using the consumer of interest provides valuable insight as to which of the potential indicator FAs in the food items are actually conserved in consumer tissues (Cook et al. 2000). ANOVA is also appropriate for evaluating levels of indicator FAs in food and consumers in controlled feeding studies (Hall et al. 2006, Kelly et al. 2008,2009 ). As with any statistical test, care should be taken to distinguish statistical significance from biological significance, as small within-group variance (especially common in controlled feeding studies) can produce a statistically significant result even when levels of the indicator are similar among groups (Budge et al. 2006).

\section{COMBINING STABLE ISOTOPE AND FA ANALYSES}

Stable isotope (SI) and FA analysis have similar advantages over estimating diet based on gut contents and direct observation, but the methods differ in their spatial variability and their ability to distinguish certain primary producers (Richoux \& Froneman 2008, Guest et al. 2010). SI signatures of primary producers are mainly influenced by environmental factors such as light, temperature, and $\mathrm{CO}_{2}$ availability, while FA signatures are also strongly influenced by physiological processes (Guest et al. 2010). SIs are well-suited to distinguishing among macroalgae and various classes of vascular plants (Peterson 1999), but in some cases they cannot be used to estimate bacterial contribution to a benthic food web because isotopic signatures of sediments tend to overlap with those of primary producers (Richoux \& Froneman $2007,2008)$. The carbon isotopic values of benthic diatoms also overlap with those of major macroalgal taxa, making their contribution to consumer diets difficult to estimate using SIs alone (Newell et al. 1995). FA analysis can easily distinguish bacteria and diatoms from other primary producers, and therefore is well-suited for characterizing benthic food webs which may have significant bacterial and microalgal components (Sargent et al. 1987, Kharlamenko et al. 2001, Richoux \& Froneman 2008). Nitrogen isotopic ratios are enriched with each trophic transfer, which can be used to indicate the trophic level of consumers (Peterson 1999). This enrichment varies to some extent with diet and should be checked in controlled feeding studies (McCutchan et al. 2003), but cross- 
validation between $\delta^{15} \mathrm{~N}$ and indicator FAs may prove useful for determining trophic level. The complementary characteristics of SI and FA analysis have led to an increasing number of studies using both tracers (Guest et al. 2010).

\section{Bulk SI analysis with FA analysis}

Bulk SI analysis (i.e. based on tissue samples as opposed to isolated compounds) is commonly used to complement FA analysis as a means of cross-validating results, particularly when 1 type of tracer is insufficient to separate all food sources. In an estuary in northern New Zealand, mangroves and seagrass were well separated using carbon isotope ratios, but the $\delta^{13} \mathrm{C}$ values of most consumers fell between those of seagrass and brown algae, which were not well separated (Alfaro et al. 2006). Seagrass and brown algae had distinct indicator FAs, however, as did other food sources including diatoms and bacteria, so the presence of these indicator FAs in consumer tissues was used to identify their diets (Alfaro et al. 2006). In a temperate estuary in South Africa, the crab Cleistostoma edwardsii and gastropod Haminoea alfredensis both had highly enriched $\delta^{13} \mathrm{C}$ values, suggesting seagrass, epibionts, or surface sediments as a major carbon source (Richoux \& Froneman 2007). FA analyses in a complementary study identified high levels of the diatom indicator 20:5n-3 in these animals, indicating that epibionts were the most likely food source (Richoux \& Froneman 2008). FA analysis of whelks Thais clavigera and bivalves Saccostrea cucullata and Septifer virgatus in nearshore shallow habitats in Hong Kong showed only that all 3 had similar levels of indicators for dinoflagellates and zooplankton, but carbon and nitrogen isotope ratios of food sources and consumers revealed that $T$. clavigera preys primarily on the suspension-feeding bivalves (Wai et al. 2008). Levels of the seagrass FA indicators $18: 2 n-6$ and $18: 3 n-3$ were relatively low in all consumers in a seagrass bed in the Sea of Japan (Kharlamenko et al. 2001), but these FAs are also precursors for PUFA synthesis, so FA results alone could not be used to conclusively rule out the importance of seagrass to these consumers. Carbon isotope ratios can be used to estimate the contribution of seagrass-derived carbon because seagrass tends to differ from other primary producers in its carbon isotopic composition (Kharlamenko et al. 2001, Alfaro et al. 2006). Carbon isotope ratios of consumers indicated that the majority of consumers derived at least half of their carbon from seagrass, and that grazers consumed a combination of seagrass and epiphytes (Kharlamenko et al. 2001). In a seagrass bed in the Baltic Sea, $\delta^{13} \mathrm{C}$ values of seagrass overlapped with those of epiphytes, but were distinct from those of sand microflora and a red macroalga (Jaschinski et al. 2011). Because the level of the seagrass indicator FA 18:4n-3 was low in all consumers, seagrass was considered an unlikely food source and was removed from the SI mixing model. Based on indicator FAs and SI data, diets of most mesograzers appeared to shift from epiphytes to sand microflora when epiphytes were scarce (Jaschinski et al. 2011).

Because FA tracers can be ambiguous with regard to a consumer's trophic level, nitrogen isotopes are a particularly valuable source of additional information in FA studies of food webs (Richoux \& Froneman 2007, Guest et al. 2010, Jaschinski et al. 2011). The FA composition of the polychaete Perenereis nuntia vallata in a temperate estuary in South Africa contained high levels of PUFAs and diatom indicators, as well as elevated bacterial FA, which taken alone would likely indicate surface deposit feeding (Richoux \& Froneman 2008). However, the $\delta^{15} \mathrm{~N}$ signature was also enriched, suggesting that $P$. nuntia vallata also consumes animal material and may obtain some of its tracer FA by consuming other deposit feeders (Richoux \& Froneman 2007). Both the $\delta^{15} \mathrm{~N}$ signature and abundance of the carnivory indicator FA 18:1n-9 were seasonally enriched in the omnivorous isopod Idotea baltica, suggesting that I. baltica consumes more animal material when epiphytes are scarce (Jaschinski et al. 2011). Sea urchins Strongylocentrotus droebachiensis in low-productivity habitats offshore from kelp beds had more enriched $\delta^{15} \mathrm{~N}$ signatures with increasing distance from the kelp bed, suggesting that they consumed more animal material as the availability of drift kelp decreased (Kelly et al. 2012). FAs identified as indicators for kelp (18:1n-9, 18:4n-3, 20:4n-6) were present in sea urchins at all sites and distances from the kelp bed, but there was no detectable spatial pattern in their relative abundance.

\section{SIs of indicator FAs}

Compound-specific SI analysis of individual FAs can help to discern trophic pathways with greater resolution than is possible with bulk SI analysis or FA analysis alone. Pond et al. (2002) used $\delta^{13} \mathrm{C}$ ratios of indicator FAs to investigate the source of PUFAs in deep-sea hydrothermal vent worms. In the tubeworm Ridgea piscesae, $\delta^{13} \mathrm{C}$ values of $16: 1 \mathrm{n}-7$ and 
18:1n-7 indicated a chemosynthetic origin for these FAs, which is consistent with the reliance of $R$. piscesae on endosymbiotic bacteria (Pond et al. 2002). However, $\delta^{13} \mathrm{C}$ values for 20:4n-6 and 20:5n-3 were closer to expected values for photosynthetic microplankton. Similarly, in the mixotrophic tubeworm Protis hydrothermica, $\delta^{13} \mathrm{C}$ values for 20:5n-3 were consistent with a chemosynthetic origin, but values for 22:6n-3 suggested a photosynthetic origin. Although other studies have found PUFA synthesis by bacteria (Jøstensen \& Landfald 1997), these results indicate that chemosynthetic bacteria are not the only source of PUFAs for R. piscesae and P. hydrothermica, and that other sources, including synthesis by the tubeworms, should be investigated (Pond et al. 2002). Jack et al. (2009) compared diets of rock lobster Jasus edwardsii in 3 marine reserves in New Zealand using bulk SI analysis and $\delta^{13} \mathrm{C}$ values of selected indicator FAs. Bulk SI analysis revealed that rock lobsters in 2 of the 3 reserves used suspended particulate matter and macroalgae as their basal carbon sources, suggesting that they preyed on the abundant filter-feeding mussel Mytilus edulis galloprovincialis. Carbon and nitrogen isotope signatures of rock lobsters from the third reserve suggested that carbon from terrestrial detritus or chemoautotrophic bacteria contributed significantly to their diets, and elevated 16:1n-7 indicated the presence of either diatoms or bacteria. The $\delta^{13} \mathrm{C}$ value for $16: 1 \mathrm{n}-7$ from these lobsters was within the expected range for sulfur-oxidizing bacteria, and the authors concluded that the symbiont-bearing clam Solemya parkinsonii is the most likely food source for the rock lobsters in the third reserve. Ice algal diatoms in the Arctic were distinct from pelagic diatoms in their FA composition, but $\delta^{13} \mathrm{C}$ values of the diatom tracers $16: 4 \mathrm{n}-1$ and 20:5n-3 enabled the use of mixing models to quantitatively estimate the contribution of each diatom source to higher trophic levels (Budge et al. 2008).

\section{RECOMMENDATIONS AND DIRECTIONS FOR FUTURE RESEARCH}

Both the complexity of benthic food webs and the ability of consumers to modify dietary FAs introduce sources of error to studies using FAs in benthic habitats, but the reliability of results can be improved by considering these factors when designing a study. An effort should be made to characterize the FA composition of as many likely food sources as possible so that indicator FAs in the consumer can be attributed to the correct source. Whenever possible, potential food sources should be collected from the same habitat as the consumers, rather than using literature values from another habitat, because indicator levels are variable even among closely-related species, and a single FA may have several sources in some habitats. Ideally, the transfer of indicator FAs from food to consumer should be verified in controlled feeding experiments before indicators are used in field studies. Data from these experiments should be examined for evidence of FA biosynthesis and selective retention. The lack of unique FA markers for any species imparts uncertainty to the interpretation of FA data, such that inferences are always stronger when corroborated with data from direct observation, gut contents, or SI analysis. The use of FAs in field studies of benthic food webs should be limited to (1) classifying consumers into trophic groups, (2) identifying FAs associated with trophic groups, and (3) detecting unusual foods with unique or rare indicator FAs. These studies should be undertaken with attention to potentially confounding variation in FA composition with tissue type, reproductive status, and season.

As with most ecological methods, appropriate allocation of sampling effort and use of statistical techniques are important in studies using FA analysis. FAs of consumers may be highly variable among replicates, so relatively large sample sizes may be required to detect differences among groups. Similarity-based measures have relatively few constraints and are appropriate for most FA datasets. Univariate statistics can be used to test for differences in FA levels among groups, but these should be corrected for multiple comparisons. Because of the limited resolution of FA data and complex FA metabolism of consumers, the results of FA studies in benthic systems thus far have been qualitative. Quantitative estimates of contents of mixed diets using FA analysis are possible in seabirds and marine mammals, but these techniques require careful calibration even for consumers with limited ability to modify dietary FAs (Iverson et al. 2004) and may therefore be impractical for invertebrates.

The application of FA analysis to benthic food webs has revealed trophic relationships in habitats that are otherwise difficult or impossible to study, traced the fate of primary production through detrital and other pathways, and confirmed linkages that were previously detected using other methods. Benthic communities pose certain challenges for FA analysis in that they often contain many potential food sources, and consumers may be capable of modifying their dietary FAs. A balanced approach that includes field sampling and controlled feeding experiments, multivari- 
ate and univariate analyses, and cross-validation with other methods will generally yield the best results.

Despite the limitations of FA analysis in benthic food webs, some studies suggest promising areas for further investigation. These include (1) measuring FA assimilation by invertebrates through comparison of tissue and fecal FA profiles in controlled feeding studies (Hall et al. 2006); (2) using indicator FAs to detect non-native food sources such as aquaculture waste (Cook et al. 2000); and (3) the use of speciesspecific dietary markers, such as NMI FAs for benthic invertebrates (Budge et al. 2007) or sterols for primary producers (Brown \& Belt 2012), as these may provide more reliable results than either FA or SI analysis.

Acknowledgements. We thank S. Budge, S. Iverson, T. Romanuk, H. Lotze, and H. Guderley for helpful discussions of this work, and 4 anonymous reviewers for their comments on an earlier draft of this paper. J.R.K. was supported by a Killam Predoctoral Scholarship and an NSERC Canada Graduate Scholarship.

\section{LITERATURE CITED}

Alfaro AC, Thomas F, Sergent L, Duxbury M (2006) Identification of trophic interactions within an estuarine food web (northern New Zealand) using fatty acid biomarkers and stable isotopes. Estuar Coast Shelf Sci 70:271-286

Allen CE, Tyler PA, Van Dover CL (2001) Lipid composition of the hydrothermal vent clam Calyptogena pacifica (Mollusca: Bivalvia) as a trophic indicator. J Mar Biol Assoc UK 81:817-821

Anderson MJ (2001) A new method for non-parametric multivariate analysis of variance. Austral Ecol 26:32-46

Anderson MJ (2005) PERMANOVA: a FORTRAN computer program for permutational multivariate analysis of variance. Department of Statistics, University of Auckland

> Bachok Z, Mfilinge PL, Tsuchiya M (2003) The diet of the mud clam Geloina coaxans (Mollusca, Bivalvia) as indicated by fatty acid markers in a subtropical mangrove forest of Okinawa, Japan. J Exp Mar Biol Ecol 292: 187-197

Bell MV, Tocher DR (2009) Biosynthesis of polyunsaturated fatty acids in aquatic ecosystems: general pathways and new directions. In: Arts MT, Kainz MJ, Brett MT (eds) Lipids in aquatic ecosystems. Springer, Dordrecht, p 211-236

Bell MV, Dick JR, Kelly MS (2001) Biosynthesis of eicosapentaneoic acid in the sea urchin Psammechinus miliaris. Lipids 36:79-82

Ben-Mlih F, Marty JC, Fiala-Medioni A (1992) Fatty acid composition in deep hydrothermal vent symbiotic bivalves. J Lipid Res 33:1797-1806

Bergé JP, Barnathan G (2005) Fatty acids from lipids of marine organisms: molecular biodiversity, roles as biomarkers, biologically active compounds, and economical aspects. Adv Biochem Eng Biotechnol 96:49-125
Brown TA, Belt ST (2012) Identification of the sea ice diatom biomarker $\mathrm{IP}_{25}$ in Arctic benthic macrofauna: direct evidence for a sea ice diatom diet in Arctic heterotrophs. Polar Biol 35:131-137

> Budge SM, Parrish CC (1998) Lipid biogeochemistry of plankton, settling matter and sediments in Trinity Bay, Newfoundland. II. Fatty acids. Org Geochem 29: 1547-1559

> Budge SM, Parrish CC, McKenzie CH (2001) Fatty acid composition of phytoplankton, settling particulate matter and sediments at a sheltered bivalve aquaculture site. Mar Chem 76:285-303

Budge SM, Iverson SJ, Bowen WD, Ackman RG (2002) Among- and within-species variability in fatty acid signatures of marine fish and invertebrates on the Scotian Shelf, Georges Bank, and southern Gulf of St. Lawrence. Can J Fish Aquat Sci 59:886-898

Budge SM, Iverson SJ, Koopman HN (2006) Studying trophic ecology in marine ecosystems using fatty acids: a primer on analysis and interpretation. Mar Mamm Sci 22:759-801

> Budge SM, Springer AM, Iverson SJ, Sheffield G (2007) Fatty acid biomarkers reveal niche separation in an Arctic benthic food web. Mar Ecol Prog Ser 336:305-309

> Budge SM, Wooller MJ, Springer AM, Iverson SJ, McRoy CP, Divoky GJ (2008) Tracing carbon flow in an arctic marine food web using fatty acid-stable isotope analysis. Oecologia 157:117-129

Calado R, Rosa R, Morais S, Nunes ML, Narciso L (2005) Growth, survival, lipid and fatty acid profile of juvenile monaco shrimp Lysmata seticaudata fed on different diets. Aquac Res 36:493-504

> Canuel EA, Cloern JE, Ringelberg DB, Guckert JB, Rau GH (1995) Molecular and isotopic tracers used to examine sources of organic matter and its incorporation into the food webs of San Francisco bay. Limnol Oceanogr 40: 67-81

Carpenter EJ, Harvey HR, Fry B, Capone DG (1997) Biogeochemical tracers of the marine cyanobacterium Trichodesmium. Deep Sea Res I 44:27-38

Castell JD, Kennedy EJ, Robinson SMC, Parsons GJ, Blair TJ, Gonzalez-Duran E (2004) Effect of dietary lipids on fatty acid composition and metabolism in juvenile green sea urchins (Strongylocentrotus droebachiensis). Aquaculture 242:417-435

Clarke KR (1993) Non-parametric multivariate analyses of changes in community structure. Aust J Ecol 18:117-143

Clarke KR, Gorley RN (2006) PRIMER v6: user manual/tutorial. PRIMER-E, Plymouth

> Clarke KR, Green RH (1988) Statistical design and analysis for a 'biological effects' study. Mar Ecol Prog Ser 46:213-226

> Clarke KR, Somerfield PJ, Gorley RN (2008) Testing of null hypotheses in exploratory community analyses: similarity profiles and biota-environment linkage. J Exp Mar Biol Ecol 366:56-69

Colaço A, Desbruyères D, Guezennec J (2007) Polar lipid fatty acids as indicators of trophic associations in a deepsea vent system community. Mar Ecol 28:15-24

> Cook EJ, Bell MV, Black KD, Kelly MS (2000) Fatty acid compositions of gonadal material and diets of the sea urchin, Psammechinus milaris: trophic and nutritional implications. J Exp Mar Biol Ecol 255:261-274

Cook EJ, Shucksmith R, Orr H, Ashton GV, Berge J (2010) Fatty acid composition as a dietary indicator of the inva- 
sive caprellid, Caprella mutica (Crustacea: Amphipoda). Mar Biol 157:19-27

Crawley KR, Hyndes GA, Vanderklift MA, Revill AT, Nichols PD (2009) Allochthonous brown algae are the primary food source for consumers in a temperate, coastal environment. Mar Ecol Prog Ser 376:33-44

D'Souza FML, Loneragan NR (1999) Effects of monospecific and mixed-algae diets on survival, development and fatty acid composition of penaeid prawn (Penaeus spp.) larvae. Mar Biol 133:621-633

> Dalsgaard J, St. John M, Kattner G, Müller-Navarra D, Hagen W (2003) Fatty acid trophic markers in the pelagic marine environment. Adv Mar Biol 46:225-340

> Drazen JC, Phleger CF, Guest MA, Nichols PD (2008a) Lipid, sterols and fatty acid composition of abyssal holothurians and ophiuroids from the north-east Pacific Ocean: food web implications. Comp Biochem Physiol B Biochem Mol Biol 151:79-87

> Drazen JC, Phleger CF, Guest MA, Nichols PD (2008b) Lipids, sterols and fatty acids of abyssal polychaetes, crustaceans, and a cnidarian from the northeast Pacific Ocean: food web implications. Mar Ecol Prog Ser 372:157-167

> Drazen JC, Phleger CF, Guest MA, Nichols PD (2009) Lipid composition and diet inferences in abyssal macrourids of the eastern North Pacific. Mar Ecol Prog Ser 387:1-14

Dunstan GA, Volkman JK, Barrett SM, Leroi JM, Jeffery SW (1994) Essential polyunsaturated fatty acids from 14 species of diatom (Bacillariophyceae). Phytochemistry 35: 155-161

Fernandez-Jover D, Jimenez JAL, Sanchez-Jerez P, BayleSempere J, Casalduero FG, Lopez FJM, Dempster T (2007) Changes in body condition and fatty acid composition of wild Mediterranean horse mackerel (Trachurus mediterraneus, Steindachner, 1868) associated to sea cage fish farms. Mar Environ Res 63:1-18

> Fleurence J, Gutbier G, Mabeau S, Leray C (1994) Fatty acids from 11 marine macroalgae of the French Brittany coast. J Appl Phycol 6:527-532

Gillan FT, Hogg RW (1984) A method for the estimation of bacterial biomass and community structure in mangrove-associated sediments. J Microbiol Methods 2: 275-293

Ginger ML, Santos VLCS, Wolff GA (2000) A preliminary investigation of the lipids of abyssal holothurians from the north-east Atlantic ocean. J Mar Biol Assoc UK 80: 139-146

> Glencross BD, Smith DM (1999) The dietary linoleic and linolenic fatty acids requirements of the prawn Penaeus monodon. Aquac Nutr 5:53-63

> Graeve M, Kattner G, Piepenburg D (1997) Lipids in Arctic benthos: does the fatty acid and alcohol composition reflect feeding and trophic interactions? Polar Biol 18: 53-61

> Graeve M, Dauby P, Scailteur Y (2001) Combined lipid, fatty acid and digestive tract content analyses: a penetrating approach to estimate feeding modes of Antarctic amphipods. Polar Biol 24:853-862

> Graeve M, Kattner G, Wiencke C, Karsten U (2002) Fatty acid composition of Arctic and Antarctic macroalgae: indicator of phylogenetic and trophic relationships. Mar Ecol Prog Ser 231:67-74

Guest MA, Nichols PD, Frusher SD, Hirst AJ (2008) Evidence of abalone (Haliotis rubra) diet from combined fatty acid and stable isotope analyses. Mar Biol 153:579-588
Guest MA, Hirst AJ, Nichols PD, Frusher SD (2010) Multiscale spatial variation of stable isotope and fatty acid profiles amongst temperate reef species: implications for design and interpretation of trophic studies. Mar Ecol Prog Ser 410:25-41

Gurr MI, Harwood JL, Frayn KN (2002) Lipid biochemistry. Blackwell Science, Oxford

Hagen W, Kattner G, Friedrich C (2000) The lipid compositions of high-Antarctic notothenioid fish species with different life strategies. Polar Biol 23:785-791

Hair JF, Black WC, Babin BJ, Anderson RE, Tatham RL (2006) Multivariate data analysis. Prentice Hall, Upper Saddle River, NJ

Hall D, Lee SY, Meziane T (2006) Fatty acids as trophic tracers in an experimental estuarine food chain: tracer transfer. J Exp Mar Biol Ecol 336:42-53

> Honya M, Kinoshita T, Ishikawa M, Mori H, Nisizawa K (1994) Seasonal variation in the lipid content of cultured Laminaria japonica: fatty acids, sterols, $\beta$-carotene and tocopherol. J Appl Phycol 6:25-29

Howell KL, Pond DW, Billett DSM, Tyler PA (2003) Feeding ecology of deep-sea seastars (Echinodermata: Asteroidea): a fatty-acid biomarker approach. Mar Ecol Prog Ser 255: 193-206

Hughes AD, Catarino AI, Kelly MS, Barnes DKA, Black KD (2005) Gonad fatty acids and trophic interactions of the echinoid Psammechinus miliaris. Mar Ecol Prog Ser 305: 101-111

Hughes AD, Kelly MS, Barnes DKA, Catarino AI, Black KD (2006) The dual functions of sea urchin gonads are reflected in the temporal variations of their biochemistry. Mar Biol 148:789-798

Iverson SJ (2009) Tracing aquatic food webs using fatty acids: from qualitative indicators to quantitative determination. In: Arts MT, Kainz MJ, Brett MT (eds) Lipids in aquatic ecosystems. Springer, Dordrecht, p 281-307

Iverson SJ, Field C, Bowen WD, Blanchard W (2004) Quantitative fatty acid signature analysis: a new method of estimating predator diets. Ecol Monogr 74:211-235

Jack L, Wing SR, McLeod RJ (2009) Prey base shifts in red rock lobster Jasus edwardsii in response to habitat conversion in Fiordland marine reserves: implications for effective spatial management. Mar Ecol Prog Ser 381: 213-222

Jaschinski S, Brepohl DC, Sommer U (2011) Seasonal variation in carbon sources of mesograzers and small predators in an eelgrass community: stable isotope and fatty acid analyses. Mar Ecol Prog Ser 431:69-82

Jøstensen JP, Landfald B (1997) High prevalence of polyunsaturated-fatty-acid producing bacteria in arctic invertebrates. FEMS Microbiol Lett 151:95-101

Kelly JR, Scheibling RE, Iverson SJ, Gagnon P (2008) Fatty acid profiles in the gonads of the sea urchin Strongylocentrotus droebachiensis on natural algal diets. Mar Ecol Prog Ser 373:1-9

Kelly JR, Scheibling RE, Iverson SJ (2009) Fatty acids tracers for native and invasive macroalgae in an experimental food web. Mar Ecol Prog Ser 391:53-63

Kelly JR, Krumhansl KA, Scheibling RE (2012) Drift algae subsidies to sea urchins in low-productivity habitats. Mar Ecol Prog Ser (in press) doi: 10.3354/meps09628

Kharlamenko VI, Zhukova NV, Khotimchenko SV, Svetashev VI, Kamenev GM (1995) Fatty-acids as markers of food sources in a shallow-water hydrothermal ecosystem (Kraternaya Bight, Yankich Island, Kurile Islands). Mar 
Ecol Prog Ser 120:231-241

Kharlamenko VI, Kiyashko SI, Imbs AB, Vyshkvartzev DI (2001) Identification of food sources of invertebrates from the seagrass Zostera marina community using carbon and sulfur stable isotope ratio and fatty acid analyses. Mar Ecol Prog Ser 220:103-117

Khotimchenko SV (1998) Fatty acids of brown algae from the Russian Far East. Phytochemistry 49:2363-2369

Khotimchenko SV (2003) Fatty acids of species in the genus Codium. Bot Mar 46:456-460

Khotimchenko SV (2005) Lipids from the marine alga Gracilaria verrucosa. Chem Nat Compd 41:285-288

> Khotimchenko SV, Kulikova IV (1999) Lipids of two species of brown algae of the genus Laminaria. Chem Nat Compd 35:17-20

Khotimchenko SV, Vaskovsky VE, Titlyanova TV (2002) Fatty acids of marine algae from the Pacific coast of North California. Bot Mar 45:17-22

Latyshev NA, Khardin AS, Kasyanov SP, Ivanova MB (2004) A study on the feeding ecology of chitons using analysis of gut contents and fatty acid markers. J Molluscan Stud 70:225-230

Li X, Fan X, Han L, Lou Q (2002) Fatty acids of some algae from the Bohai Sea. Phytochemistry 59:157-161

> Liu H, Kelly MS, Cook EJ, Black K, Orr H, Xin Zhu J, Lin Dong $S$ (2007) The effect of diet type on growth and fatty-acid composition of sea urchin larvae, Paracentrotus lividus (Lamarck, 1816) (Echinodermata). Aquaculture 264:247-262

> Liyana-Pathirana C, Shahidi F, Whittick A (2002) The effect of an artificial diet on the biochemical composition of the gonads of the sea urchin (Strongylocentrotus droebachiensis). Food Chem 79:461-472

- Mansour MP, Volkman JK, Jackson AE, Blackburn SI (1999) The fatty acid and sterol composition of five marine dinoflagellates. J Phycol 35:710-720

Mateos HT, Lewandowski PA, Su XQ (2010) Seasonal variations of total lipid and fatty acid contents in muscle, gonad and digestive glands of farmed Jade Tiger hybrid abalone in Australia. Food Chem 123:436-441

> McCutchan JH, Lewis WM, Kendall C, McGrath CC (2003) Variation in trophic shift for stable isotope ratios of carbon, nitrogen and sulfur. Oikos 102:378-390

McLeod RJ, Wing SR (2009) Strong pathways for incorporation of terrestrially derived organic matter into benthic communities. Estuar Coast Shelf Sci 82:645-653

- Meziane T, Tsuchiya M (2000) Fatty acids as tracers of organic matter in the sediment and food web of a mangrove/intertidal flat system, Okinawa, Japan. Mar Ecol Prog Ser 200:49-57

- Meziane T, Tsuchiya M (2002) Organic matter in a subtropical mangrove-estuary subjected to wastewater discharge: origin and utilisation by two macrozoobenthic species. J Sea Res 47:1-11

Meziane T, Bodineau L, Retiere C, Thoumelin G (1997) The use of lipid markers to define sources of organic matter in sediment and food web of the intertidal salt-marsh-flat ecosystem of Mont-Saint-Michel bay, France. J Sea Res 38:47-58

Meziane T, Sanabe MC, Tsuchiya M (2002) Role of fiddler crabs of a subtropical intertidal flat on the fate of sedimentary fatty acids. J Exp Mar Biol Ecol 270:191-201

> Meziane T, d'Agata F, Lee SY (2006) Fate of mangrove organic matter along a subtropical estuary: small-scale exportation and contribution to the food of crab commu- nities. Mar Ecol Prog Ser 312:15-27

> Navarro JC, McEvoy LA, Bell MV, Amat F, Hontoria F, Sargent JR (1997) Effect of different dietary levels of docosahexaenoic acid (DHA, 22:6 $\omega$-3) on the DHA composition of lipid classes in sea bass larvae eyes. Aquac Int 5: 509-516

Nelson MM, Phleger CF, Nichols PD (2002) Seasonal lipid composition in macroalgae of the northeastern Pacific Ocean. Bot Mar 45:58-65

> Newell RIE, Marshall N, Sasekumar A, Chong VC (1995) Relative importance of benthic microalgae, phytoplankton, and mangroves as sources of nutrition for penaeid prawns and other coastal invertebrates from Malaysia. Mar Biol 123:595-606

> Nichols PD, Klumpp DW, Johns RB (1986) Lipid components and utilization in consumers of a seagrass community: an indication of carbon source. Comp Biochem Physiol B Comp Biochem 83:103-113

Nichols DS, Nichols PD, McMeekin TA (1993) Polyunsaturated fatty acids in Antarctic bacteria. Antarct Sci 5: $149-160$

> Ortiz J, Uquiche E, Robert P, Romero N, Quitral V, Llanten C (2009) Functional and nutritional value of the Chilean seaweeds Codium fragile, Gracilaria chilensis and Macrocystis pyrifera. Eur J Lipid Sci Technol 111:320-327

Parkes RJ, Taylor J (1983) The relationship between fatty acid distributions and bacterial respiratory types in contemporary marine sediments. Estuar Coast Shelf Sci 16: 173-174

Parrish CC, Deibel D, Thompson RJ (2009) Effect of sinking spring phytoplankton blooms on lipid content and composition in suprabenthic and benthic invertebrates in a cold ocean coastal environment. Mar Ecol Prog Ser 391:33-51

Peterson BJ (1999) Stable isotopes as tracers of organic matter input and transfer in benthic food webs: a review. Acta Oecol 20:479-487

> Phleger CF, Nelson MM, Groce AK, Cary SC, Coyne KJ, Nichols PD (2005) Lipid composition of deep-sea hydrothermal vent tubeworm Riftia pachyptila, crabs Munidopsis subsquamosa and Bythograea thermydron, mussels Bathymodiolus sp. and limpets Lepetodrilus spp. Comp Biochem Physiol B Comp Biochem 141:196-210

Piché J, Iverson SJ, Parrish FA, Dollar R (2010) Characterization of forage fish and invertebrates in the Northwestern Hawaiian Islands using fatty acid signatures: species and ecological groups. Mar Ecol Prog Ser 418:1-15

> Pond DW, Dixon DR, Bell MV, Fallick AE, Sargent JR (1997) Occurrence of 16:2(n-4) and 18:2(n-4) fatty acids in the lipids of the hydrothermal vent shrimps Rimicaris exoculata and Alvinocaris markensis: nutritional and trophic implications. Mar Ecol Prog Ser 156:167-174

> Pond DW, Allen CE, Bell MV, Van Dover CL, Fallick AE, Dixon DR, Sargent JR (2002) Origins of long-chain polyunsaturated fatty acids in the hydrothermal vent worms Ridgea piscesae and Protis hydrothermica. Mar Ecol Prog Ser 225:219-226

> Renaud SM, Parry DL, Thinh LV (1994) Microalgae for use in tropical aquaculture. I: Gross chemical and fatty acid composition of twelve species of microalgae from the Northern Territory, Australia. J Appl Phycol 6:337-345

> Renaud SM, Thinh LV, Parry DL (1999) The gross chemical composition and fatty acid composition of 18 species of tropical Australian microalgae for possible use in mariculture. Aquaculture 170:147-159 
Richoux NB, Froneman PW (2007) Assessment of spatial variation in carbon utilization by benthic and pelagic invertebrates in a temperate South African estuary using stable isotope signatures. Estuar Coast Shelf Sci 71: 545-558

Richoux NB, Froneman PW (2008) Trophic ecology of dominant zooplankton and macrofauna in a temperate, oligotrophic South African estuary: a fatty acid approach. Mar Ecol Prog Ser 357:121-137

Russell NJ, Nichols DS (1999) Polyunsaturated fatty acids in marine bacteria - a dogma rewritten. Microbiology 145: 767-779

Sanina NM, Goncharova SN, Kostetsky EY (2004) Fatty acid composition of individual polar lipid classes from marine macrophytes. Phytochemistry 65:721-730

Sargent JR, Falk-Petersen S (1988) The lipid biochemistry of calanoid copepods. Hydrobiologia 167-168:101-114

Sargent JR, Parkes RJ, Mueller-Harvey I, Henderson RJ (1987) Lipid biomarkers in marine ecology. In: Sleigh MA (ed) Microbes in the sea. Ellis Horwood, Chichester, p 119-138

Sargent J, Bell G, McEvoy L, Tocher D, Estevez A (1999) Recent developments in the essential fatty acid nutrition of fish. Aquaculture 177:191-199

Shin PKS, Yip KM, Xu WZ, Wong WH, Cheung SG (2008) Fatty acid as markers to demonstrating trophic relationships among diatoms, rotifers and green-lipped mussels. J Exp Mar Biol Ecol 357:75-84

Smith SJ, Iverson SJ, Bowen WD (1997) Fatty acid signatures and classification trees: new tools for investigating the foraging ecology of seals. Can J Fish Aquat Sci 54: $1377-1386$

Soudant P, Moal J, Marty Y, Samain JF (1996) Impact of the quality of dietary fatty acids on metabolism and the composition of polar lipid classes in female gonads of Pecten maximus (L.). J Exp Mar Biol Ecol 205:149-163

Spychalla JP, Kinney AJ, Browse J (1997) Identification of an animal $\omega$-3 fatty acid desaturase by heterologous expression in Arabidopsis. Proc Natl Acad Sci USA 94:1142-1147

> Suprayudi MA, Takeuchi T, Hamasaki K (2004) Essential fatty acids for larval mud crab Scylla serrata: implications of lack of the ability to bioconvert C18 unsaturated fatty acids to highly unsaturated fatty acids. Aquaculture 231: 403-416

Takagi T, Eaton CA, Ackman RG (1980) Distribution of fatty acids in lipids of the common Atlantic sea urchin Strongylocentrotus droebachiensis. Can J Fish Aquat Sci 37:195-202

Thurber AR (2007) Diets of Antarctic sponges: links between the pelagic microbial loop and benthic metazoan food web. Mar Ecol Prog Ser 351:77-89

> Usup G, Hamid SZ, Chiet PK, Wah CK, Ahmad A (2008) Marked differences in fatty acid profiles of some planktonic and benthic marine dinoflagellates from Malaysian waters. Phycologia 47:105-111

Vaskovsky VE, Khotimchenko SV, Xia B, Li H (1996) Polar lipids and fatty acids of some marine macrophytes from the Yellow Sea. Phytochemistry 42:1347-1356

Viso AC, Marty JC (1993) Fatty acids from 28 marine macroalgae. Phytochemistry 34:1521-1533

Volkman JK, Jeffrey SW, Nichols PD, Rogers GI, Garland CD (1989) Fatty acid and lipid composition of 10 species of microalgae used in mariculture. J Exp Mar Biol Ecol 128:219-240

Wai TC, Ng JSS, Leung KMY, Dudgeon D, Williams GA (2008) The source and fate of organic matter and the significance of detrital pathways in a tropical coastal ecosystem. Limnol Oceanogr 53:1479-1492

Warton DI, Hui FKC (2011) The arcsine is asinine: the analysis of proportions in ecology. Ecology 92:3-10 
Appendix 1. Summary of fatty acids (FAs) used as dietary tracers in selected studies of benthic food webs. Non-methylene-interrupted (NMI) FAs are those with double bonds not separated by a methyl group $\left(\mathrm{CH}_{2}\right)$; prefixes ' $\mathrm{i}$ ' and 'ai' indicate a methyl branch at the second or third carbon from the terminal methyl group, respectively (i.e. branched FAs). MUFA: monounsaturated FA; PUFA: polyunsaturated FA; LCFA: long-chain FA

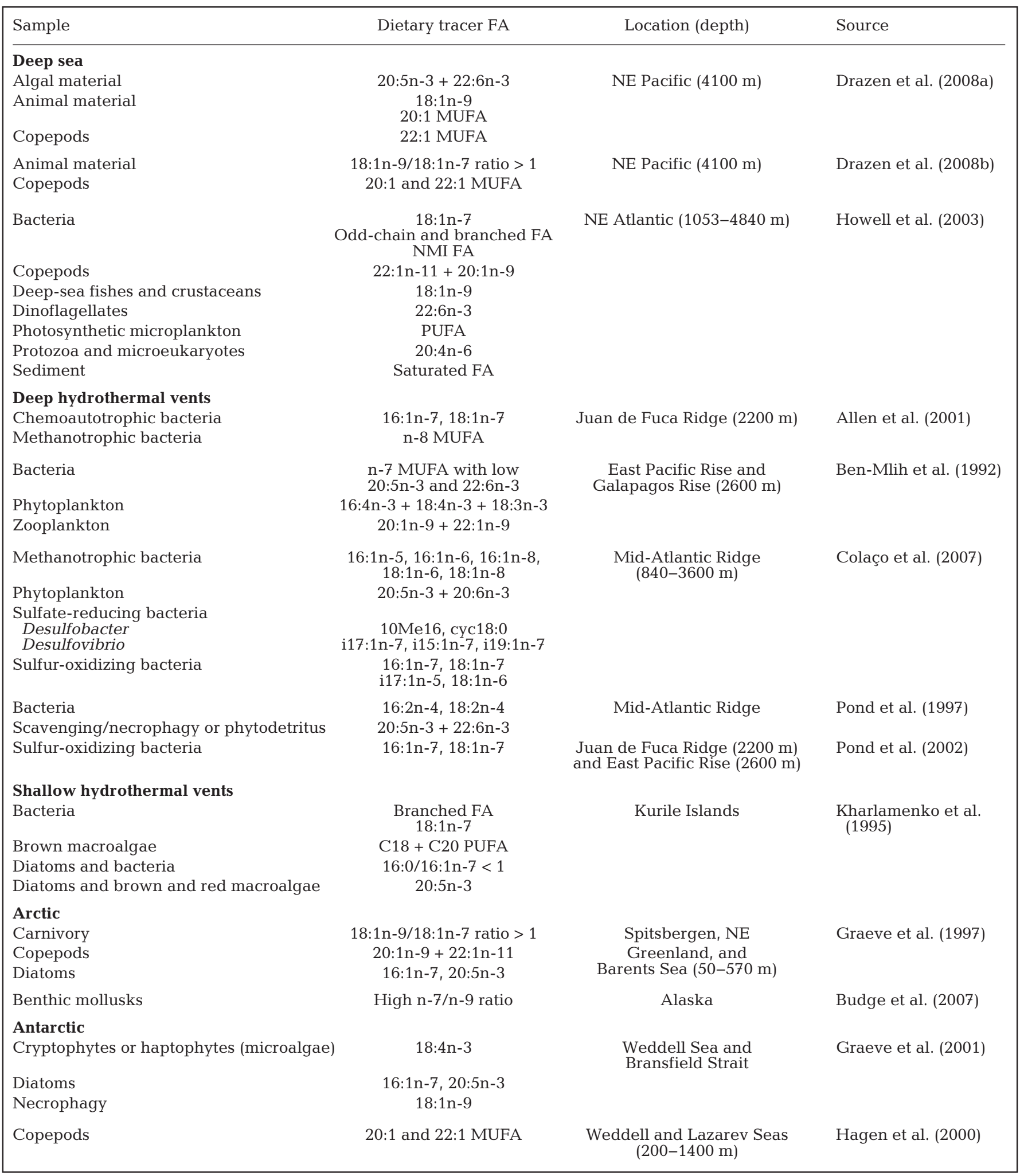


Appendix 1 (continued)

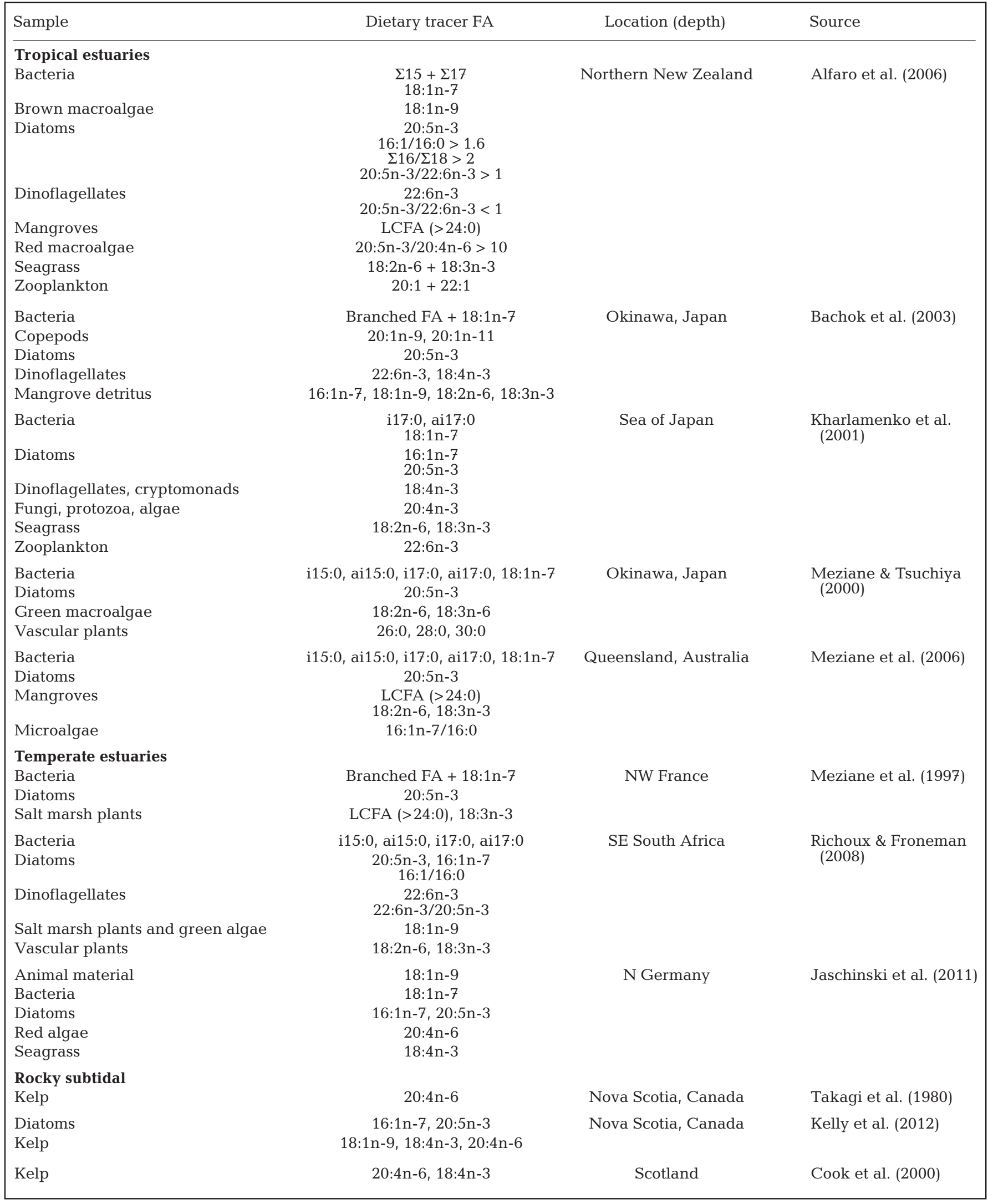

